\title{
Assessment of sex selection in Bangladesh
}

Md. Noorunnabi Talukder

Population Council

Ubaidur Rob

Population Council

Forhana Rahman Noor

Population Council

Follow this and additional works at: https://knowledgecommons.popcouncil.org/departments_sbsr-rh

Part of the Demography, Population, and Ecology Commons, Family, Life Course, and Society Commons, Gender and Sexuality Commons, International Public Health Commons, Maternal and Child Health Commons, and the Women's Health Commons How does access to this work benefit you? Let us know!

\section{Recommended Citation}

Talukder, Md. Noorunnabi, Ubaidur Rob, and Forhana Rahman Noor. 2014. "Assessment of sex selection in Bangladesh." Dhaka: Population Council. 


\section{ASSESSMENT OF SEX SELECTION IN BANGLADESH}

MD. NOORUNNABI TALUKDER

UBAIDUR ROB

FORHANA RAHMAN NOOR

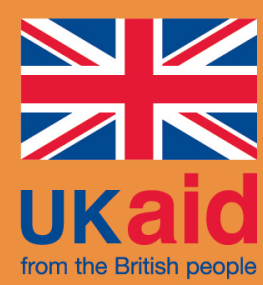

2 POPULATION COUNCIL 


\title{
ASSESSMENT OF SEX SELECTION IN BANGLADESH
}

\author{
MD. NOORUNNABI TALUKDER \\ UBAIDUR ROB \\ FORHANA RAHMAN NOOR
}

2014
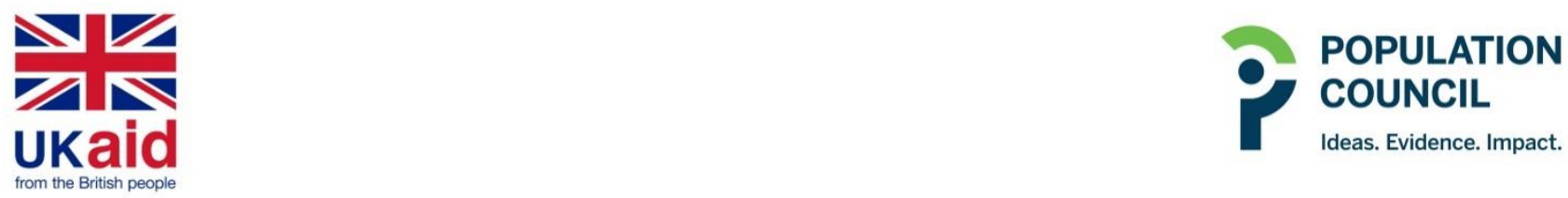


\section{POPULATION 7 COUNCIL \\ Ideas. Evidence. Impact.}

The Population Council confronts critical health and development issues-from stopping the spread of HIV to improving reproductive health and ensuring that young people lead full and productive lives. Through biomedical, social science, and public health research in 50 countries, we work with our partners to deliver solutions that lead to more effective policies, programs, and technologies that improve lives around the world. Established in 1952 and headquartered in New York, the Council is a nongovernmental, nonprofit organization governed by an international board of trustees.

Population Council Bangladesh Country Office

House 15B, Road 13, Gulshan 1

Dhaka 1212, Bangladesh

Email: info.bangladesh@popcouncil.org

popcouncil.org

Suggested citation: Talukder, M.N., U. Rob, and F.R. Noor. 2014. "Assessment of Sex Selection in Bangladesh." Dhaka: Population Council. 


\section{CONTENTS}

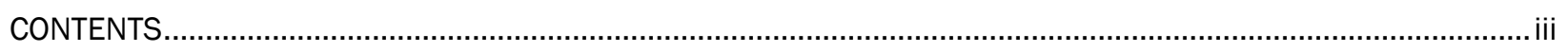

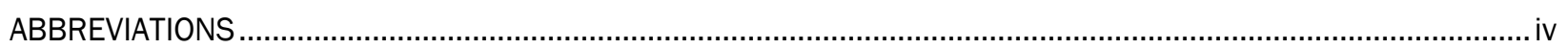

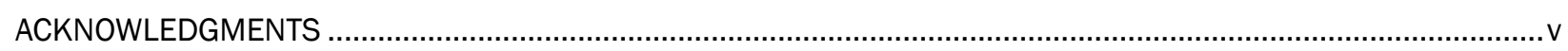

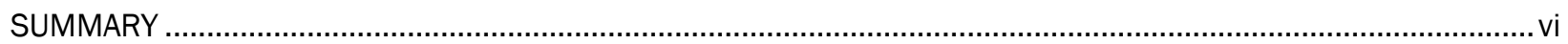

Closing the gap between desired and actual SRB .....................................................................................

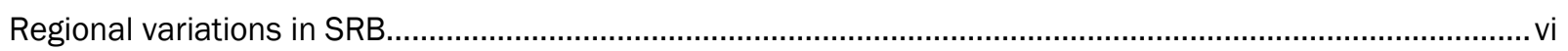

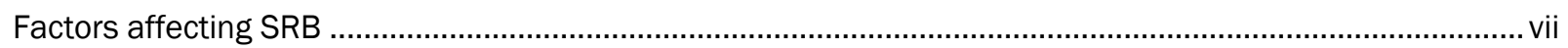

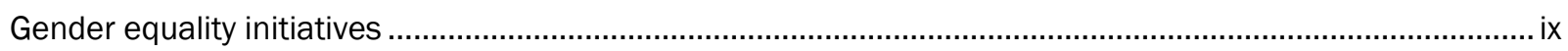

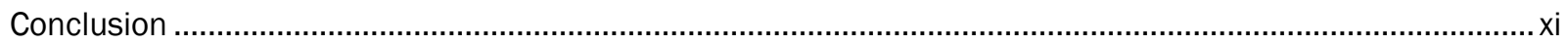

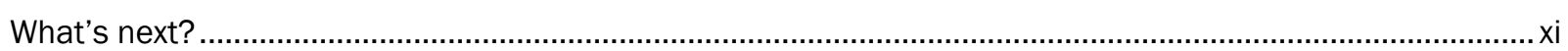

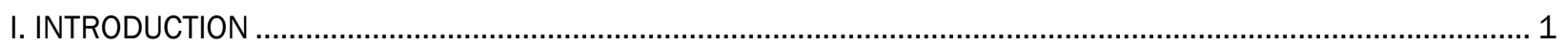

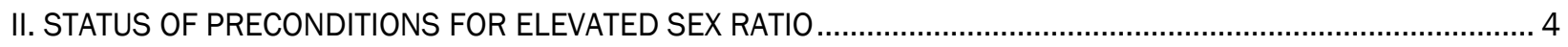

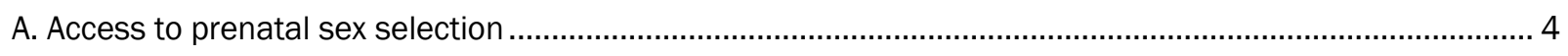

B. Son preference

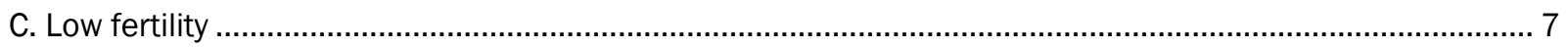

III. TRENDS AND DIFFERENTIALS IN SEX RATIO AT BIRTH AND FACTORS CONTRIBUTING TO ADVERSE SEX

RATIOS

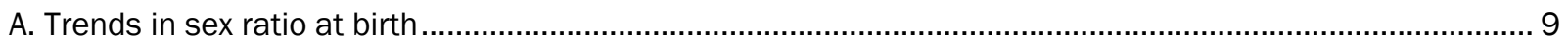

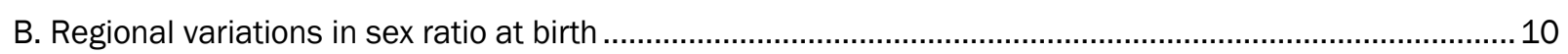

C. Socio-demographic differentials in sex ratio at birth ................................................................................. 15

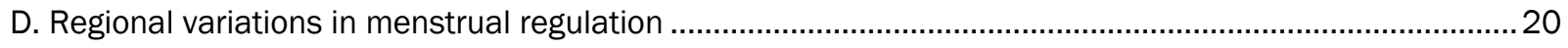

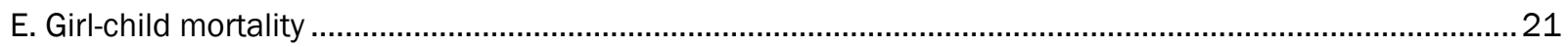

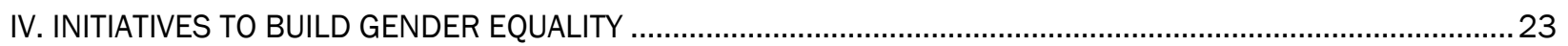

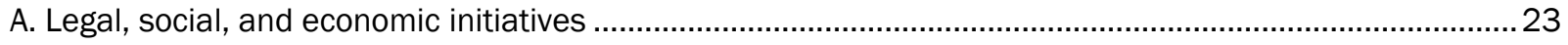

Laws, policies, and institutions promoting gender equality …................................................................ 23

Laws on the use of technology for prenatal sex selection...................................................................... 24

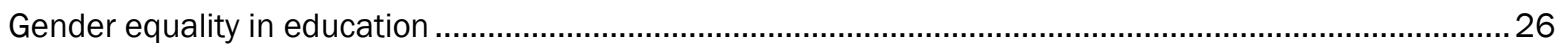

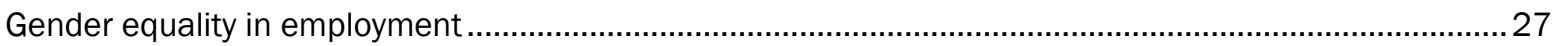

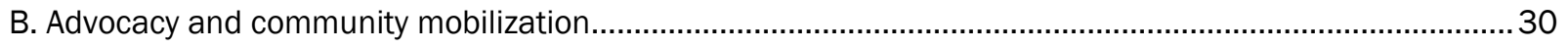

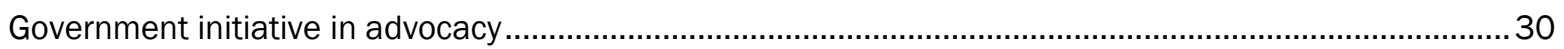

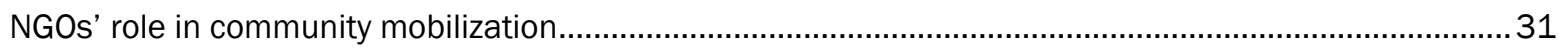

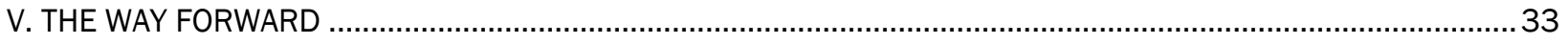

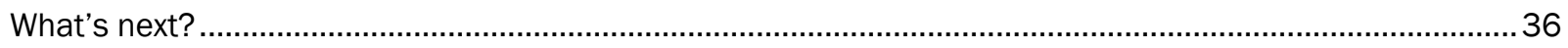

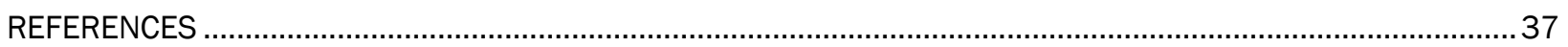




\section{ABBREVIATIONS}

\begin{tabular}{ll} 
BPFA & Beijing Platform for Action \\
CCT & Conditional Cash Transfer \\
CEDAW & Convention on the Elimination of All Forms of Discrimination Against Women \\
CVS & Chorionic Villus Sampling \\
DFID & Department for International Development \\
DHS & Demographic and Health Survey \\
DNA & Deoxyribonucleic Acid \\
DSRB & Desired Sex Ratio at Birth \\
FSSP & Female Secondary-School Stipend Project \\
GOB & Government of Bangladesh \\
ICDDR,B & International Center for Diarrheal Disease Research, Bangladesh \\
MICS & Multiple Indicator Cluster Survey \\
MR & Menstrual Regulation \\
NGO & Nongovernmental Organization \\
OSRB & Observed Sex Ratio at Birth \\
RMG & Readymade Garment \\
SRAB & Sex Ratio of All Births \\
SRB & Sex Ratio at Birth \\
SRLB & Sex Ratio of Last Birth \\
U5MR & Under-five Mortality Rate \\
UN & United Nations \\
UNFPA & United Nations Population Fund \\
& \\
\hline
\end{tabular}




\section{ACKNOWLEDGMENTS}

We are grateful to the UK Department for International Development (UKaid) for providing the funding for this research project, and to Nupur Barua, Deputy Head, South Asia Research Hub at the Department for International Development (DFID), British High Commission, New Delhi, for technical assistance and support.

We sincerely thank Naila Kabeer, Professor, Gender Institute, London School of Economics and Political Science, United Kingdom, and Mohammad Bellal Hossain, Associate Professor, Department of Population Sciences, University of Dhaka, Bangladesh, for comments on the draft of the report. Thanks are due to Shireen Jejeebhoy, Senior Associate, Population Council, for comments on an earlier draft of the report. 


\section{SUMMARY}

Under normal circumstances, more boys than girls are born in nature to compensate for the higher mortality of males; the expected "natural order" ratio is considered 105 males for every 100 females born. According to UN estimates, the sex ratio at birth (SRB) has persisted at its natural level of 105 male per 100 female newborns for the past half century in Bangladesh. Generally, the SRB becomes skewed in a setting where fertility is declining or low and where son preference exists. Strong son preference compounded by the availability of measures to implement such preference can lead to increased SRB. For example, the increasing availability of prenatal diagnostic technologies, together with declining fertility desires and persistent son preference, has contributed to increased genderbiased sex selection in several Asian countries, including China and India. As Bangladesh experiences rapid decline in fertility to reach replacement-level fertility, it is critical to unmask the mystery behind its SRB. However, there is an absence of intensive studies and an inadequacy of data focusing on SRB in Bangladesh. This literature review analyzes Demographic and Health Survey (DHS) data to understand the dynamics of SRB in Bangladesh. The study also examines the efforts that have contributed to closing the gender gap in social and economic opportunities and raising the value of girls and women.

\section{Closing the gap between desired and actual SRB}

Analysis of DHS data ${ }^{1}$ suggests that the SRB has remained almost the same in the past two decades in Bangladesh, at 103 male per 100 female newborns, lower than the UN estimate of 105 males. Generally, the desired sex ratio at birth (DSRB) exceeds the observed sex ratio at birth (OSRB) in developing countries (Bongaarts 2013). The present study, using DHS data, estimates that the DSRB exceeds the OSRB by a considerable margin in Bangladesh (111 vs. 103). Findings also suggest that the difference between desired and actual sex ratios has progressively narrowed over time. The DSRB has declined from 124 in the 1990s to 111 in 2011, suggestive of a possible shift from a culture of strong son preference. As the fertility transition is well underway in the country, fertilitylimiting behavior such as adopting contraception or abortion after a male child is born may be held responsible for lower actual SRB than desired.

\section{Regional variations in SRB}

Bangladesh is administratively divided into seven divisions. According to DHS data, regional variations in sex ratio are characterized by an east-west divide. Women from two western divisions (Khulna and Rajshahi) have SRB not exceeding 96, while women from one eastern division (Sylhet) have a highly unbalanced composition of boys over girls (SRB: 112). Like the observed SRB, the DSRB among divisions is patterned by an east-west divide. High desired ratios (DSRB 113 or above) are found in two eastern divisions (Sylhet and Chittagong), while two western divisions (Khulna and Rajshahi) have a ratio lower than 109. Relatively higher SRB, both desired and actual, in the eastern region indicates a preference for male children. DHS data also reveal an east-west divide in terms of sex composition of children desired, as women in the western divisions (Khulna, Rajshahi, and

\footnotetext{
${ }^{1}$ Caution should be exercised in interpreting the value of the sex ratios that originate from DHS data, because the size of samples is not adequate for a reliable estimate of SRB. The ideal sources for such data are the census and birth registration records. However, using DHS data is useful because it allows a look at SRB differentials across many characteristics, most of which are not available from birth registration and census data.
} 
Rangpur) expressed lower preferences for male children than women in the eastern divisions (Sylhet and Chittagong). Research is needed to determine what factors contribute to high SRB in the eastern region.

\section{Factors affecting SRB}

Elevation in SRB is caused by three factors as identified by Guilmoto (2009): access to sex-selection technology; preference for sons; and low fertility. Bangladesh is a low-fertility country (total fertility rate stands at 2.3) where there are potential risks for elevation in SRB with the presence of two other preconditions, e.g., sex-selection technology and son preference.

Access to sex-selection technology partially exists in the country. Ultrasound is the only available technology for sex detection in Bangladesh, but the use of this technology for sex detection is not common even in the absence of policies/laws on the use of prenatal diagnostic techniques for sex selection. Many women undergo ultrasound scanning, largely to check the health and position of the fetus. Moreover, ultrasound scanning tends to be done too late in the pregnancy to allow legal abortion (Huq et al. 2012). The country is yet to introduce any technology for testing the DNA of the fetus for prenatal sex determination in the early gestational period.

Bangladesh is unique in permitting the provision of menstrual regulation (MR) services as part of the government family-planning program. Overall, the rate of pregnancy terminations (both MR and induced abortion) in the country is high but it is not clear whether abortions are sex-selective or not. Incidence of sex-selective abortion is supposedly low in Bangladesh because of the large volume of legal pregnancy terminations within ten weeks of gestation (without knowing the fetal sex) under the MR policy and the unavailability of DNA testing for sex detection in the early gestational period. Generally, skewed SRB is related to the high rate of abortion. Paradoxically, in the eastern region of Bangladesh, higher SRB coexists with the lowest level of pregnancy termination (MR). Overall, Bangladesh is yet to be threatened by high SRB, and therefore no prohibition exists on sex-selective abortion, as is the case for several developing countries in Asia, including China and India.

The desire to have a small family or to limit childbearing has become increasingly common over the past decades as witnessed by the huge increase in the proportion of eligible women with two children who desire to stop childbearing-from 58 to 82 percent (NIPORT et al. 2013). Bangladesh has experienced a sharp decline in the mean ideal number of children that eligible women wantfrom 4.5 to 2.2 during the past two decades (NIPORT et al. 2013). In line with the decline of the ideal number of children, the average number of children per woman declined from 4.3 in 1991 to 2.3 in 2011 (NIPORT et al. 2013). Economic hardship and the cost of raising children are found to be strong determinants for desiring a small family (Gipson and Hindin 2009; Islam and Chowdhury 2012). Gipson and Hindin (2009) observed that men appear too rigid about wanting a large family and incidence of pregnancy increased among couples in which only the husband wanted more children.

Despite small families becoming the norm, there is still a presence of son preference among couples. Gipson and Hindin (2009) noted that couples with two daughters and no son are more likely to have a subsequent pregnancy than couples with two or more children and at least one son. DHS 
data also indicate higher future fertility intention among couples who have two girls than among couples with two boys (36 percent vs. 17percent). Saha and Bairagi (2007) estimated that in the absence of a preference for male children there would be a reduction of about 0.2 in the national total fertility rate. Although the preference for sons was present, couples also wanted a daughter. More specifically, those who had at least one son and a daughter had the lowest fertility (Saha and Bairagi 2007).

Recent changes in gender preference among couples are encouraging. There is a strong preference among couples for a balanced sex composition of children, which is becoming a common norm over time across the country. The popularity of "one boy and one girl" is about to become universal, as only nine percent of the women with such a balanced sex composition of children want an additional child in the future. Moreover, the preference for a greater number of sons than daughters has decreased markedly over the past two decades. It is also encouraging to note the drastic reduction in the proportion of women with two girls intending to have an additional child. Two decades earlier, 64 percent of women with two girls wanted an additional child, suggesting that they were not satisfied with the composition, and this has sharply reduced to 36 percent over time. All these improvements are encouraging, and the culture of son preference appears to be giving way to a growing indifference to the sex of a child. How couples achieve a small family with balanced sex composition of children is a matter for further research. Whether efforts to encourage gender equality or the strong family planning program has contributed to such progression toward the norm of a balanced-gendered small family is yet to be explored.

A weakening of the preference for male children is evident from fertility ideals among young women. The desired SRB is positively associated with increasing parity. The preference for more sons than daughters is stronger among older women than women in younger age groups. Largely, a woman's desire for a male child is likely to be affected by her level of education and wealth status. The preference for more sons than daughters is remarkably lower among women with higher-level education (i.e., above secondary level). Likewise, the preference for sons over daughters decreases with increasing household wealth status. The rural setting exhibits a preference for male children. Women living in rural areas have a stronger desire to have more sons than daughters, compared with their urban counterparts.

Traditionally, the country is characterized by an absence of moral acceptance of sex selection as DHS data reveal no change in observed sex ratios at birth over the past two decades (102 in 1993 and 103 in 2011). Son preference is not strongly linked to religion in Bangladesh, which is a moderate Muslim country where more than 90 percent of the population practices Islam as a religion. Son preference is not an Islamic practice, as this religion does not promote strong son preference for religious ceremonies and family inheritance. A study by Kabeer et al. (2013) explored a stronger son preference among Hindu women than among Muslim women in Bangladesh.

Generally, strong preference for sons leads couples to discriminate between the sexes in different ways. In many societies that have high SRB, son preference is manifested at three stages in the couple's fertility behavior: before conception, during pregnancy (prenatal), and during early childhood (postnatal). 
In Bangladesh, son preference and family-building strategies are widely practiced before conception. Sex composition of the child/children already born influences the couple's decision to use contraceptive methods or to have an additional child. The sex ratio of last birth (SRLB) bears witness to this phenomenon. The country has witnessed an ascent in SRLB from 117 in 1993 to 125 in 2011. The rise in SRLB in the country is consistent with the linkage of the reproductive outcomes for couples who want exactly one son and who stop childbearing after a son is born. DHS data also reveal that women with five or six children have a sex ratio at birth of around 90, indicating a higher number of daughters than sons. A similar context was illustrated by Bongaarts (2013) that in a population in which this particular childbearing pattern prevails, couples would have exactly one son (or, in rare cases, no sons) but can have any number of daughters.

A prenatal preference for a son is not widely observed in the country. A strong small-family norm coexists with a prohibitive social culture of sex-selective abortion, yet this does not cause any abnormally high imbalances in the sex ratio. In the context of declining desired family size and increasing costs for managing unwanted births, women resort to MR or abortion as a means of fertility control. Intention to limit family size is the most common reason that married women seek MR/abortion (Bhuiya et al. 2001; Huq et al. 2012). There is no difference between eastern and western regions regarding the purpose of abortion (i.e., limiting fertility) among women. A very short interval between conceptions is another reason for adopting MR/abortion (Bhuiya et al. 2001). However, there is a key concern regarding weak implementation of MR legislation. Most pregnancy terminations occur after the legal boundary of MR.

Postnatally, no strong evidence on ensuring son preference through neglect and abandonment of female children exists. An analysis of under-one and under-five mortality rates shows a positive trend for girls and would point to an absence of systematic discrimination against girls at this early stage. Lower mortality among girls than boys during infancy and early childhood also suggests a tendency toward gender equality. Improvements in the survival chances of girls relative to boys may be driven by the weakening of son preference (Kabeer et al. 2013).

\section{Gender equality initiatives}

Bangladesh has started to experience societal change toward valuing daughters as highly as sons. Earlier, security was linked with dependence on men and hence sons were valued more than daughters. With the increased opportunities for education, paid employment, and microcredit, women now have greater ability to function independently and provide income support to parents that previously could be fulfilled only by sons.

\section{EDUCATION}

Gender parity has been achieved in secondary education. The increase in the rate of girls' enrollment is believed to have been brought about by a cash transfer program implemented by the government in rural areas (Khandker et al. 2003; Asadullah and Chaudhury 2006; KFW 2006; Islam and Dogra 2011). Introduced in 1994, the purpose of the nationwide conditional cash transfer (CCT) program has been to incentivize families to delay their daughters' marriages. The stipend is considered more than just financial support; it is also a symbol of encouragement and recognition of women's right to 
an education as well as an important prerequisite for transforming girls into human capital (Mahmud 2003). The stipend program appears to have created a positive attitude among community leaders and the general population toward female secondary education, which is indeed an achievement in a patriarchal society that values women's seclusion (Mahmud 2003). However, the female-stipend program has not been rigorously evaluated to assess its impact in delaying child marriage. Moreover, it is important to generate evidence regarding whether Bangladesh's success in educating its female population reduces the preference for sons.

\section{EMPLOYMENT}

Women's participation in the labor force is higher than ever. In recent years, there has been a significant change in attitude toward women taking up outside employment. Rapid expansion of the labor-intensive apparel industry and a high penetration of microfinance are two key reasons behind the higher participation rate of the female workforce in Bangladesh. Investments in female laborforce participation may have indirectly influenced gender roles and son preference. Evidence suggests that employment creates a space in which working women can begin to make choices and decisions independent of the wishes of the men in their families (Ahmed and Bould 2004; Khosla 2009). There is also evidence of a shift from the traditional patriarchal family system, as working female members of the family assist their husbands, brothers, and parents through wage employment in the context of extreme poverty and landlessness (Ahmed and Bould 2004). Similarly, Khosla (2009) recognized the capability of an adult daughter, married or unmarried, in providing financial support to her parents. Whether improved employment and economic opportunities for women bears an impact on couple's sex ratio at birth compared with non-beneficiaries requires deeper investigation.

\section{ADVOCACY AND COMMUNITY MOBILIZATION INITIATIVES}

Government role in advocacy. The government's strong and relentless advocacy for a two-child family norm for more than three decades is believed to have brought changes in the demand for small family size in the country. The role of the mass media in changing fertility levels is well recognized and documented, but evidence is lacking on media initiatives that change the value of daughters, or reduce discrimination against daughters, or affect the sex composition of children.

NGOs' role in community mobilization. Over the past three decades, a dynamic and increasingly organized nongovernmental (NGO) movement has developed in Bangladesh and a large number of organizations specifically focus on gender-equality goals. Not only are NGOs important providers of social and financial services but they also act as important conduits for new norms and values at the grassroots level (Kabeer et al. 2013). NGOs have played a key role in promoting women's economic activity in the villages of Bangladesh, helping to shift perceptions of women as liabilities to a growing perception of women as assets (Huq et al. 2012). NGO-financed development programs in rural Bangladesh have significantly raised women's participation in household decision-making in addition to conferring on women greater control over resources (Hossain and Tisdell 2005). 


\section{Conclusion}

Up until now, the growing preference for a small family with balanced sex composition of children, low female-child mortality rates, and a near-absence of sex-selective abortion in an environment of moderate Islamic culture have prevented SRB from going beyond the normal level in Bangladesh. Yet regional variation in the SRB remains a cause for concern. Further, Bangladesh may be threatened by a high SRB if son preference prevails and if medical technology that enables detection of the sex of a fetus within the early gestational period is made available.

Opportunities exist for Bangladesh to adopt measures to prevent the elevation in SRB. The country needs to formulate policies/laws forbidding sex-selection technology and ensuring strict enforcement. Policies and strategies are in place to ensure equal opportunities between men and women. Yet the expansion of social and economic opportunities for girls and women will hasten the process of reducing preferential treatment of males over females as an indirect route to reducing son preference. Mass media and social movement can also accelerate the process of reducing son preference or changing attitudes so that daughters are valued. However, for societies like Bangladesh that are still heavily rural and agrarian and where poverty is widespread, reducing son preference remains a big challenge for policymakers.

\section{What's next?}

This literature review has initiated a journey toward learning about the dynamics of the SRB in Bangladesh. The study suggests several areas for primary research that can generate evidence for policymakers that will help them understand the mystery surrounding SRB in the country.

- The truth behind the east-west divide in the SRB in the country: what factors affected the unbalanced SRB?

- Women's awareness and views on ultrasound and abortion and their use for sex selection. How couples achieve a small family with balanced sex composition of children.

- Provider views on laws and use of ultrasound, particularly for sex selection. Provider experiences regarding sex-selective abortion. 



\section{INTRODUCTION}

Compared with the population increase since its independence in 1971, Bangladesh is projected to add less population in the future. Bangladesh's population now stands at approximately 157 million (UN 2013) and average fertility is 2.3 children per woman (NIPORT et al. 2013). The fertility of Bangladeshi women has decreased by 2 children in the past two decades (NIPORT et al. 2013). Fertility transition is well underway in the country and its population has been experiencing a heavy young-age composition in the process of fertility transition since the 1990s. Nevertheless, the number of total births has started to decline since 2000, and after three decades Bangladesh is expected to have one million less births than its current level (from 3.2 million births in 2010 to 2.4 million in 2040) (UN 2013). United Nations (UN) estimates also suggest the emergence of a population with more females than males by 2030 , which will be continued throughout the rest of the century.

Normally, more boys are born than girls in nature to compensate for the higher mortality of males; the expected "natural order" ratio is considered 105 boys for every 100 females born. In the absence of manipulation, the sex ratio at birth (SRB) is remarkably consistent across human populations, with 105 to 107 male births for every 100 female births (Hesketh and Xing 2006). The world's SRB in 2010 was estimated to be 107. A highly skewed SRB of 116 is found in China, and India's level is estimated at 111 (UN 2013). China's sex ratio was near normal three decades ago, but skewed SRB became evident after the implementation of stringent fertility regulation starting in the early 1980s and it is projected to continue for about the next half century (UN 2013). Even worse, India will have a far longer history of skewed SRBs than other countries, and it will be continued throughout the rest of the century (UN 2013). China and India show a high degree of preference for sons, despite the wide differences between the two countries in industrialization, urbanization, and social development (Das Gupta et al. 2003). It has been suggested that the resort to female-selective abortion in these countries represents efforts on the part of couples to reconcile their desire for smaller families with their continued preference for sons (Das Gupta and Bhat 1997). Yet the transition to smaller families in societies characterized by son preference has not been accompanied by rising SRBs everywhere. Bangladesh, for instance, appears to have undergone fertility decline without resorting to such means (Kabeer et al. 2013). Largely, Bangladesh does not follow the Chinese and Indian patterns of high sex ratios. According to UN estimates, the SRB in Bangladesh is 105 male per 100 female newborns, and it has hovered around 105 over the past 60 years with no change projected for the remainder of the century (UN 2013).

The SRB is not static, however. Sudden rise in the SRB in China provides a useful lesson for countries in which birth rates are rapidly falling. Chang (1994) observed that in a society where each couple wants at least one son and couples are willing to use prenatal sex detection and abortion of female fetuses, then the effect of the SRB would be greater at low fertility than high fertility. The author also stated that when the desired number of children becomes small, other things being equal, the effects of son-selective reproductive behaviors on SRB for a given population are likely to be greater. 
Bangladesh has witnessed a sharp decline in the mean ideal number of children that eligible women want from 4.5 to 2.2 over the past two decades (NIPORT et al. 2013). In line with the decline of the ideal number of children, the average number of children per woman declined from 4.3 in 1991 to 2.3 in 2011 ( NIPORT et al. 2013). At present, the country's desired fertility nearly matches its observed fertility (2.2 vs. 2.3). Due to increased availability of contraception and pregnancytermination services, the gap between desired and actual fertility has narrowed in Bangladesh. A large number of women resort to pregnancy termination when they have an unwanted pregnancy. To control fertility, contraception is heavily backed by pregnancy termination ${ }^{2}$ that allows couples to avoid unwanted pregnancies in Bangladesh. In the 1993-94, 1999-2000, and 2011 Demographic and Health Surveys (DHSs), both the contraceptive prevalence rate (44.6 percent, 53.8 percent, and 61.2 percent respectively) and recourse to menstrual regulation (1.7 percent, 3.7 percent, and 9.4 percent respectively) have been increasing. ${ }^{3}$ It is not only unintended pregnancy but also the decline in desired fertility that has contributed to the increasing rate of pregnancy termination in Bangladesh. Streatfield (2001) commented that the total fertility rate would be higher in the absence of pregnancy termination. Streatfield (2001), noting an annual volume of pregnancy termination of 700,000 to 800,000 in 2001 -equivalent to about 20 percent of births or more than half a child per woman-commented that if none of these terminations occurred, hypothetically the total fertility rate would be closer to 4 against the actual fertility of 3.3 children per woman as of 2001 .

There is increasing evidence that women and girls opt for pregnancy termination from available sources that are easily accessible, affordable, and present no pressure from legislative barriers (Islam and Chowdhury 2012). Overall, the rate of pregnancy termination is high in the country. In a recent study, Vlassoff et al. (2012) estimated that 653,100 menstrual regulation (MR) procedures were performed in health facilities nationwide in 2010. In addition, an estimated 646,600 induced abortions were performed, the majority of which were unsafe (Vlassoff et al. 2012). Facilities in both public and private sectors do not have a system of keeping official records on abortion for sex selection. Generally, skewed SRBs are typically associated with high rates of pregnancy termination. Bangladesh appears to be characterized by a contrast between normal SRB and higher incidence of pregnancy termination, therefore it would be interesting to see whether any sex-selective abortion exists or not.

The observed differences in SRB among populations are caused by differences in three factors that were identified by Guilmoto (2009). Guilmoto describes the following preconditions for the sex ratio to be elevated: access to sex-selection technology; preference for sons and moral acceptance of sex selection; and low fertility, which produces a fertility squeeze. All three preconditions are typically found in populations having high sex ratios (Bongaarts 2013).

Strong son preference compounded by availability of measures to implement such preference can lead to increased SRB. Sex-determination technology allows women to resort to sex-selective abortion in the context of declining fertility (Guilmoto 2009). For example, the increasing availability of prenatal diagnostic technologies, together with declining fertility desires and persistent son

\footnotetext{
2 In Bangladesh, pregnancy termination under the guise of menstrual regulation (MR) within ten weeks of gestation is legally and widely available.

${ }^{3}$ Correct estimates of MR and abortion are difficult to obtain in the country. In the public sector, there is a system for collecting MR data but underreporting is common; estimates are even more difficult to obtain in the private sector (Vlassoff et al. 2012).
} 
preference has facilitated an increase in the occurrence of gender-biased sex selection in several Asian countries, including China and India. As Bangladesh experiences rapid decline in fertility to reach replacement-level fertility, it is critical to examine to what extent the access to technologies that can determine the sex of a fetus exists and the abortion services available in the country and their role in affecting the SRB.

To change gender-role attitudes that favor boys, the government of Bangladesh has implemented policies and programs and a range of activities. Improved gender equality in social and economic opportunities is a testimony to its commitment. Positive trends in education have been observed for girls. The gender parity in education is strongly tilted in favor of girls (UNICEF 2011). In recent decades, women's opportunities and public involvement, particularly in labor force and economic activities, have been gradually increasing (Khandaker 2013). What initiatives improve gender equality in education and economic opportunities remains to be explored. Also critical to understand is the impact of program strategies in reducing discrimination against girls and women.

The Population Council has undertaken the current research study, using a mix of literature review and analysis of data, to assess the situation and dynamics of SRB in Bangladesh. This study draws on extensive review of secondary sources to examine the role of three preconditions for sex ratios to be elevated in Bangladesh, and makes an attempt to analyze DHS data to describe the trends and differentials of SRB in the country. In addition, the study examines the initiatives that have contributed to closing the gender gap in social and economic opportunities and raising the value of girls and women.

The goal of the project is to shed light on issues of gender-biased sex selection and to make evidence-based recommendations for actions that hold promise for responding to adverse SRBs, if any. This is a four-country project involving Bangladesh, India, Nepal, and Pakistan. With financial support from UKaid, the project was implemented under the leadership of the Council's India office, with country offices responsible for implementing respective country-specific studies. 


\section{STATUS OF PRECONDITIONS FOR ELEVATED SEX RATIO}

Based on the review and synthesis of relevant published documents, the role of access to prenatal sex selection, son preference, and low fertility toward sex selection in Bangladesh is discussed below.

\section{A. Access to prenatal sex selection}

\section{ACCESS TO PRENATAL SEX-DETECTION TECHNOLOGY}

Ultrasound is the only available technology for prenatal sex detection in Bangladesh. Ultrasound technology was first introduced in government hospitals in the early 1980s. In a context where abortion was not legal, ultrasound was initially used for general health purposes and later for checking the health of a fetus when pregnancies are at risk. The private sector has been importing the technology since 1985. By the early 1990s, the technology was available in government hospitals at the district level and in private clinics at the subdistrict level. However, mobile services are still not common, and most people have to go to the district or subdistrict headquarters for an ultrasound scan (Kabeer et al. 2013). Like many developing countries, ultrasound is not widely used for sex determination in Bangladesh (Huq et al. 2012).

In the Indian context, the advent of advanced sex-detection technology has been a major factor leading to a rise in SRBs. In Bangladesh, however, the use of ultrasound technology for sex selection is rare and the country is yet to introduce advanced prenatal diagnostic techniques (such as DNA testing) for sex detection within the early gestational period. In countries having advanced medical technologies, amniocentesis and chorionic villus sampling (CVS) are performed to detect fetal abnormalities through DNA testing, but these technologies are not intended for use in sex selection. Typically, CVS is done at 10-12 weeks of gestation and amniocentesis at 15-18 weeks. Kabeer et al. (2013) noted that the availability of amniocentesis and ultrasound scanning has made prenatal sex determination possible, allowing parents to use abortion to manipulate the sex composition of live births. The use of this technology has led to highly masculine SRBs in China, India, and South Korea (Kabeer et al. 2013). In Bangladesh, there is no evidence on the use of amniocentesis or CVS for detecting a genetic abnormality/disorder or for sex selection. If needed, specialist doctors in Bangladesh refer cases (or send specimens) that require CVS or amniocentesis to India (personal communication). If made available, DNA tests for fetal sex determination in the early gestational period will be highly expensive in the economic context of Bangladesh.

Bangladesh has not been threatened by high SRB in the past and therefore has not taken any actions to reduce SRB by banning sex-selective abortion as is the case for several developing countries in Asia, including China, India, and South Korea. The need for policies/laws on the use of prenatal diagnostic techniques for sex selection is yet to be realized by policymakers in Bangladesh.

Ultrasound is rarely used in Bangladesh for sex selection despite the absence of any law forbidding the use of such technology. There is an absence of official evidence on the use of ultrasound 
technology to detect the sex of a fetus. Several studies have indicated a low use of ultrasound technology for sex-detection and even fewer noted its use for sex-selective abortion. The study by Gipson and Hindin (2008) suggests that ultrasound is hardly used for sex determination. Many women had ultrasound scanning but largely to check the health and position of the fetus. There were a few references regarding its use to detect the sex of the fetus and even fewer to sex-selective abortions. Moreover, ultrasound scanning tends to be done too late in the pregnancy to allow legal abortion. Generally, women do not practice sex-selective abortion because they believe sex cannot be ascertained by ultrasound scanning before five months, when it is too late to have an abortion (Huq et al. 2012). Pregnancy terminations at advanced gestational ages are considered more dangerous (when it is not possible to know the sex of a fetus with the available ultrasound technology) and less socially acceptable in the country (Gipson and Hindin 2008).

\section{ACCESS TO PREGNANCY TERMINATION}

The country's female-focused health service delivery system in the rural areas has enabled women to access free maternal and child health, reproductive health, and family planning services and has also succeeded in establishing a two-child family norm among couples. However, women's reproductive rights in terms of access to abortion services remain legally restricted.

\section{Laws on access to pregnancy termination}

Access to abortion services is legally restricted in Bangladesh. Abortion is illegal, permitted only as a lifesaving means (UN 2002). Restrictive abortion legislation remained in effect until 1976 when the Bangladesh National Population Policy attempted to legalize and liberalize the law on abortion within ten weeks of gestation on vast medical and social grounds. Despite having legally restricted access to abortion, Bangladesh is unique in permitting the provision of MR services as part of the government family planning program (Singh et al. 2012). Even in the presence of a restrictive abortion law, pregnancy termination takes place presumably under the guise of MR.

\section{Role of pregnancy termination in fertility control}

A number of studies have highlighted the continuing role of MR and induced abortion in regulating fertility, but there is no strong evidence of sex-selective abortion. Culturally, sex-selective abortion is much less acceptable in Bangladesh and not widely available. Razzaque et al. (2002) observed strong social stigma and religious prohibition against abortion. Gipson and Hindin (2008) explored that couples, both husbands and wives, emphatically expressed their discomfort with terminating a pregnancy for personal or religious reasons.

Instead of sex selection, women in Bangladesh undergo MR as a means of fertility control offered as part of high-quality family planning services in the context of declining desired family size and increasing costs of managing unwanted births (Rahman et al. 2001). A number of studies also identified the intention/concern to limit family size as the most common reason that married women seek abortion (Bhuiya et al. 2001; Huq et al. 2012). These studies also explained the context of seeking abortion. Women seek abortion either as a backup for the failure of contraceptive methods or as a new method for limiting family size or terminating unplanned and mistimed pregnancy. A very 
short interval between conceptions was also cited as a reason for abortion. Abortion serves as a viable way to avoid having two children in rapid succession (Bhuiya et al. 2001).

\section{B. Son preference}

In many Asian societies, a couple's desire to have sons rather than daughters is greatly influenced by long-established economic and cultural beliefs. Sons are preferred because (1) they have a higher wage-earning capacity, especially in agrarian economies; (2) they continue the family line; and (3) they are generally recipients of inheritance (Hesketh and Xing 2006). The following discussion highlights the linkages between son preference and economic or cultural factors.

Bangladesh is a moderate Muslim country where over 90 percent of the population practice Islam as a religion. Son preference is not an Islamic practice as this religion does not promote strong son preference for religious ceremonies (for example, a son is not required to perform a ritual after a parent's death). This religion ensures the right of women to inherit assets from both parental and marital relations, as opposed to the Hindu religion. However, to a certain extent, the religion promotes son preference for family inheritances because sons inherit twice the amount of assets than daughters inherit from parents. A recent study by Kabeer et al. (2013) explored a stronger son preference among Hindu women than among Muslim women in Bangladesh. The more conservative Muslims in Bangladesh-those who adhered more closely to purdah ${ }^{4}$ norms-were more likely to express son preference than those who were less conservative, however the difference was not statistically significant (Kabeer et al. 2013). Son preference is, thus, loosely connected with Muslim religion in the country.

Women in Bangladesh are dominated by a patrilineal and patriarchal kinship system that enforces the social and economic dependency of women on men and prescribes the relative lower status of women (Rahman 2012). Additionally, there are gendered stereotypes where males are considered the main earning hands for families (Islam and Chowdhury 2012). However, this is slowly changing and today there is less discrimination between sons and daughters. A study conducted by Huq et al. (2012) illustrates that parents are less likely to discriminate between sons and daughters than in the past with respect to health care and investments in human capital. Huq et al. (2012) also found that persistence of son preference among many coexisted with a weakening in preference for sons among many others along with a revaluation of daughters. Moreover, there are instances of diminishing attachment with sons as reflected in the greater tendency for sons to set up their own nuclear households and become more oriented toward their wives and children to the neglect of their parents, as opposed to their traditional attachment with, and care for, parents after marriage (Huq et al. 2012). These changes signal a gradual disappearance of traditional economic value of sons over daughters. Gradually, in the country a culture of strong son preference appears to be giving way to a growing indifference to the sex of a child (Huq et al. 2012).

The value of girls and women has started to be recognized in the country. In recent years, there has been a significant change in attitude toward women taking up outside employment. Women who feel economically valued are less likely to express son preference (Kabeer et al. 2013). Kabeer et al.

\footnotetext{
${ }^{4}$ The practice of secluding women from the view of men.
} 
(2013) explained that outside paid work was most likely to be valued by the family, and the impact of women's paid work on sex preferences is mediated by how such work is perceived by the rest of the family.

Bangladesh is the exception to the traditional practice of son preference that often leads to higher mortality among girls than boys. Lower and declining mortality rates among female children indicate a culture flourishing toward nondiscrimination of daughters and increased value of girls. There is hardly any systematic discrimination against the young female child in Bangladesh as viewed from the lens of the positive trend in the under-five mortality rate (U5MR) (UNICEF 2011). In Bangladesh, the female U5MR is lower than that of the male rate (50 per 1,000 live births vs. 57 per 1,000 live births) (NIPORT et al. 2013). While child mortality rates in the country have declined sharply, the rate of decline for female infants has been faster than for male infants (UNICEF 2011). In 2010, Bangladesh's success in reducing the female infant mortality rate helped the country receive a United Nations award on progress toward attaining the Millennium Development Goals (Islam and Dogra 2011).

\section{Low fertility}

Small family norm has become increasingly popular in Bangladesh, although age at marriage has not changed markedly over time. In the context of women marrying early and having a pattern of early childbearing, small family is achieved through changes in the demand for children. The desire to have a small family or to limit childbearing has been amplified rapidly over the past decades as revealed in the huge increase in the proportion of eligible women who have two children and who wish to stop childbearing-from 58 to 82 percent (NIPORT et al. 2013).

The preference for a small family is similar among women and men. Women's preference for a small family ( 2.2 children on average) relates to less household work and limited child care so that more time can be spent in wage labor or work for a higher income or a better career (Islam and Chowdhury 2012). Men prefer to have exactly the same number of children (NIPORT et al. 2013). Economic hardship is found to be a strong basis for desiring a small family (Gipson and Hindin 2009; Islam and Chowdhury 2012). Gipson and Hindin (2009) observed that men appear too rigid about wanting a large family and incidence of pregnancy increased among couples in which only the husband wanted more children.

Although the desire for a small family is increasing, couples still give preference to sons. Gipson and Hindin (2009) found that couples with two daughters and no son are more likely to have a subsequent pregnancy than couples with two or more children and at least one son. Saha and Bairagi (2007) estimated that in the absence of a preference for a male child there would be a reduction of about 0.2 in the national total fertility rate. Although the preference for sons was found to be present, couples also wanted a daughter. More specifically, those who had at least one son and a daughter had the lowest fertility (Saha and Bairagi 2007). Bairagi (2001) noted that as fertility has been on the decline, the effect of sex preference on childbearing becomes stronger, because couples must achieve their desired number of sons within a smaller overall number of children. In the presence of a traditional cultural preference for a male child, how couples achieve a small family with balanced sex composition of children is a matter for further research. 
Diffusion of a small family-size norm, traditional son preference, and the growing use of ultrasound with no law forbidding disclosure of the sex of a fetus are the conditions that may lead to an elevation of Bangladesh's SRB if preventive measures are not implemented. Son preference is a necessary condition for prenatal sex screening and sex-selective abortion but it is not a sufficient condition as Kim (1997) observed while examining regional differences in SRB in China and South Korea. Expression of son preference depends on, and can be strengthened by, medical technology. Without medical technology that enables identification of the sex of a fetus and sex-selective abortion, there are not many paths through which son preference affects the level of SRB (Kim 1997). It remains to be seen whether Bangladeshi populations are inclined to develop a moral acceptance of sex selection and whether the country introduces advanced prenatal diagnostic techniques for fetal sex determination-two necessary conditions that fuel the elevation in SRBs in any setting. 


\section{TRENDS AND DIFFERENTIALS IN SEX RATIO AT BIRTH AND FACTORS CONTRIBUTING TO ADVERSE SEX RATIOS}

Accurate figures for sex ratio at birth (SRB) are not possible to obtain in Bangladesh because of the inadequacy of vital statistics registration. An analysis of data from DHS surveys in Bangladesh has been done and findings are discussed in this section. These surveys do not allow for the exploration of long-range trends in SRB since data are available for only a limited number of years from 199394 to 2011. Estimates from DHS surveys may vary from estimates of other national surveys because of the size of samples, the timing of surveys, and the method of calculation. In the present study, sex ratios in young children born within the last calendar year of the survey are used as a proxy measure.

Additionally, this section discusses some key findings from the Multiple Indicator Cluster Survey (MICS) 2009 report (survey conducted by the Bangladesh Bureau of Statistics and report published by UNICEF).

\section{A. Trends in sex ratio at birth}

The 2011 DHS points out a normal SRB for Bangladesh at 103 male per 100 female newbornslower than the UN estimate of 105 males. Caution should be exercised in interpreting the value of the sex ratios that originate from DHS data, ${ }^{5}$ because the size of samples is not adequate to have a reliable estimate of SRB. Ideal sources for such data are the census and birth registration records, since the SRB needs to be calculated using a large number of births to avoid fluctuations within large confidence intervals. However, DHS data will be useful because the data allow a look at SRB differentials across several characteristics, most of which are not available from birth registration and census data. The findings that emanate from DHS data may help policymakers and researchers get a preliminary understanding of the contextual situation of SRB in the country.

The following discussion is based on the analysis of data from 1993-94, 1999-2000, and 2011 DHSs. The analysis of DHS data shows a nearly same observed sex ratio at birth (OSRB) in favor of males within the period of two decades (102 in 1993 and 103 in 2011). On the other hand, a higher male-biased sex ratio is witnessed for the desired sex ratio at birth (DSRB) and the sex ratio of last birth (SRLB). A dramatic fall from 126 to 111 is noticed in the case of the DSRB. Currently, the DSRB is notably higher than the OSRB (111 vs. 103). Stagnancy in the OSRB and reduction in the DSRB have contributed to narrowing the gap between these two sex ratios over time. On the other hand, the SRLB rose from 117 to 125 (Figure 1). The SRLB is ascending even though the DSRB declines because couples are increasingly able to implement sex-specific stopping behavior. Bongaarts (2013) stated that the SRLB is a highly sensitive indicator of sex-selective stopping behavior. Bongaarts used a comparison of OSRB, DSRB, and SRLB for measuring the level of implementation of son preference. In line with the assumptions of Bongaarts (2013), the condition of normal OSRB,

${ }^{5}$ DHS 2011 had a total sample of 17,842 and within the last calendar year of the survey 1,661 births were reported, which constitutes the sample size for analyzing observed SRB. Samples from earlier DHSs for estimating observed ratio are even smaller. On the other hand, DSRB has been estimated by using the total sample of the surveys. 
high DSRB, and high SRLB in Bangladesh testifies to the presence of son preference and contraceptive stopping behavior but little or no sex-selective abortion. The rise in the SRLB in the country is consistent with the linkage of the reproductive outcomes for couples who want exactly one son as exemplified by Bongaarts (2013). In other words, childbearing continues until the last birth is that of a boy, and after having a boy couples stop childbearing.

FIGURE 1: Trend in Desired Sex Ratio at Birth, Observed Sex Ratio at Birth, and Sex Ratio of Last Birth in Bangladesh, 1993-2011

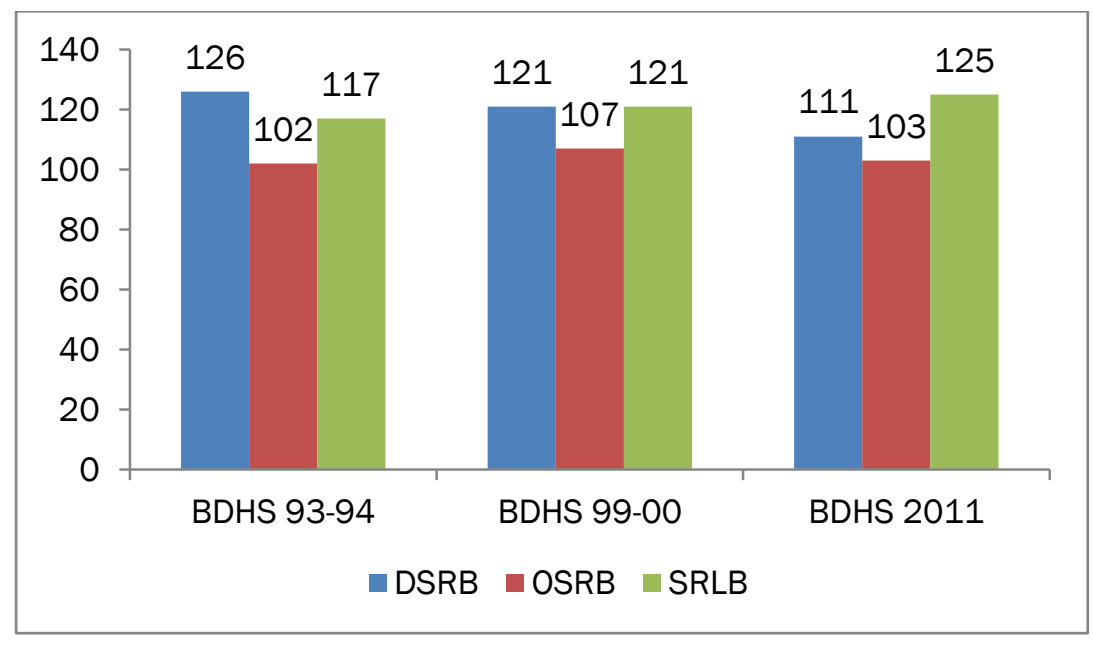

Source: DHS data.

According to Bongaarts's classification, Bangladesh is approaching a late and end-transition period where the sex ratio lies within the natural level. There are signs that the country is experiencing a weakening of son preference because the society has started to value girls, but the desired sex ratio has always been higher than the actual sex ratio. Most couples use contraception to limit fertility and some resort to abortion to maintain a small family. Many couples with son preferences practice at least some sex-specific stopping behavior. In Bangladesh, the volume of pregnancy terminations performed primarily for fertility control is considerably large, as mentioned earlier. In the context of decline in desired fertility and increased availability of pregnancy termination services, the gap between desired and actual SRB narrowed in Bangladesh, which is in line with the postulations made by Bongaarts (2013) in his multicountry study on sex selection.

\section{B. Regional variations in sex ratio at birth}

Bangladesh is a predominantly rural country where cities are home to 28 percent of the population (UN 2013). Comparison of the OSRB between urban and rural areas indicates that urban women are more likely to have unusually higher numbers of sons than daughters at birth. A reverse situation exists for the DSRB because the women living in rural areas have a stronger desire to have more sons than daughters, compared with their urban counterparts (Figure 2). The rural setting exhibits a culture of greater DSRB than OSRB, suggestive of indifference among couples to the sex of the children born. In the urban setting, actual SRB matches desired SRB, which may be caused by greater use of sex-selective stopping behavior. 
FIGURE 2: Variations in Desired and Observed Sex Ratio at Birth by Place of Residence, Bangladesh, 2011

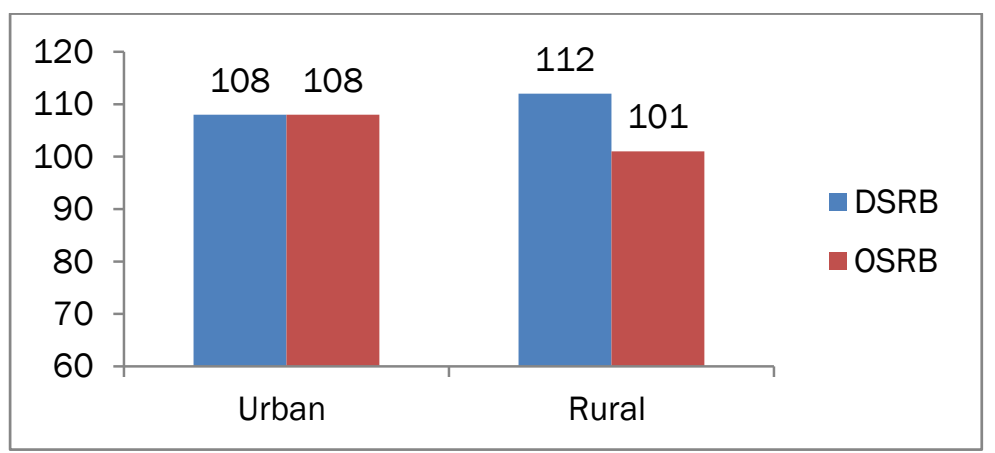

Source: DHS data.

Bangladesh is administratively divided into 7 divisions and 64 districts. Of the 7 divisions, Khulna, Rajshahi, and Rangpur are located in the western part of the country, Chittagong and Sylhet are eastern regions, and Dhaka and Barisal lie in between (the middle region). Figure 3 and Map 1 show regional variations in sex ratios, which is characterized by a divide between west and east/middle.

According to DHS data, variations in the DSRB across regions are small (from 109 to 113) while corresponding variations in the OSRB are large (ranging from 97 to 112). The western region had less boys than girls at birth (OSRB: 97) while the eastern and middle regions had more boys than girls at birth (OSRB in the middle region: 112; OSRB in the eastern region: 104). Like the OSRB, the DSRB is lowest in the western region while a slightly higher ratio is found for the two other regions (Figure 3).

All three regions exhibit a desire for a greater number of sons than daughters, with a small variation in the DSRB across regions, indicating a nearly similar fertility ideal regarding the sex composition of children. The middle region shows no difference between observed and desired sex ratios, while a large gap lies between observed and desired sex ratios in two other regions (Figure 3).

FIGURE 3: Variations in Desired and Observed Sex Ratio at Birth by Regions, Bangladesh, 2011

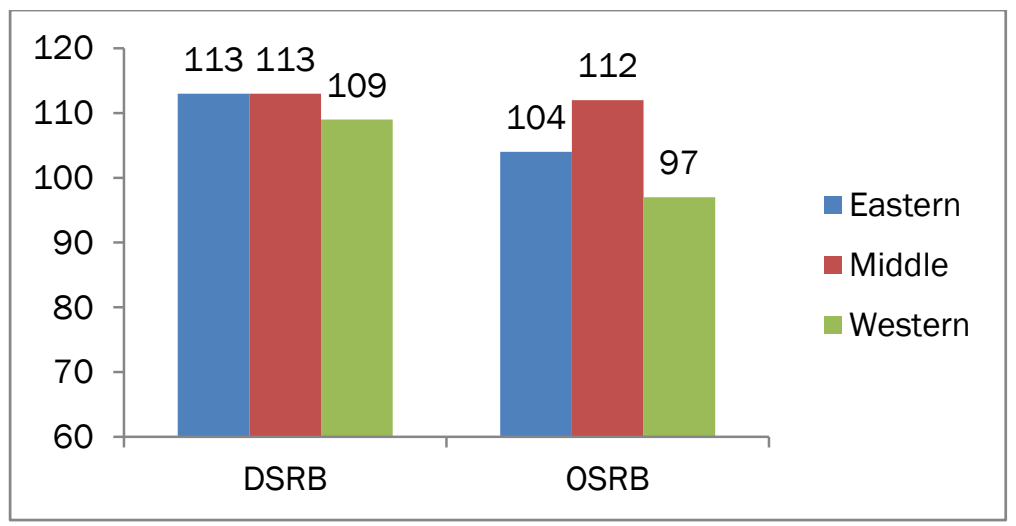

Source: DHS data. 
MAP 1: Regional Variations in the Desired and Observed Sex Ratio at Birth by Divisions in Bangladesh, 2011

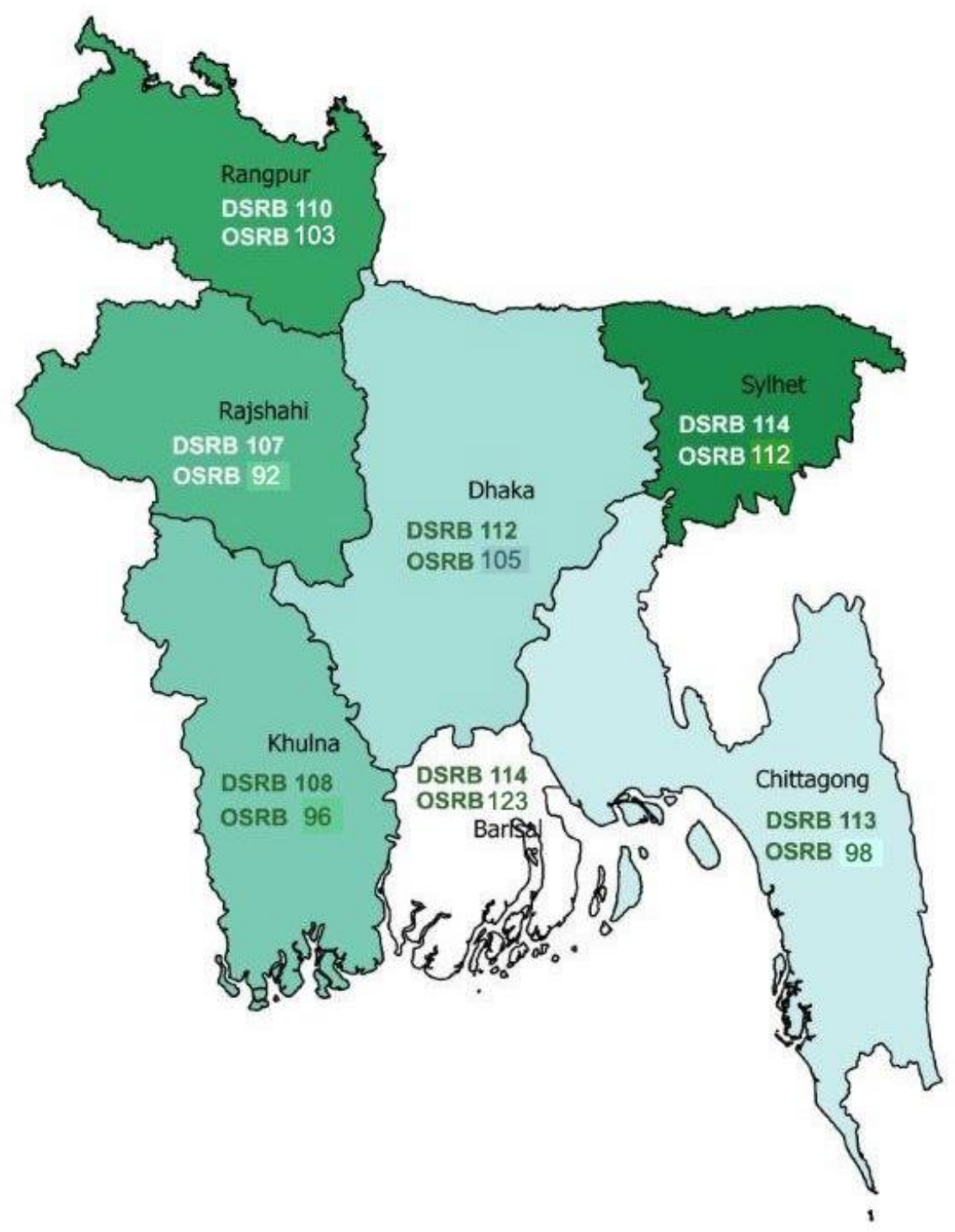

DSRB $=$ Desired sex ratio at birth. OSRB $=$ Observed sex ratio at birth. Source: DHS data. 
Estimates of sex ratio at the district level are readily available from the MICS 2009 Report, ${ }^{6}$ which exposes an unusual variation in under-one sex ratio across 64 districts in the country, ranging from 92-128 with an average of 108 (UNICEF 2011).

A distribution of districts by regions according to the level of under-one sex ratio is presented in Table 1. Out of 64 districts, 25 have a normal $(<105)$ and 15 have a near-normal under-one sex ratio (106-109). Two-thirds of the districts in western and middle regions have a normal and near-normal under-one sex ratio. Encouragingly, couples in one-fourth of the districts in western and middle regions have a balanced or girl-favored sex ratio (sex ratio $\leq 100$ ). On the other hand, sex ratios of 109 and below are noticed in only one-third of the districts in the eastern region. Twenty-four districts (out of 64) have a highly unbalanced sex ratio of 110 and above. Ten out of these 24 districts are located in the eastern region (Table 1), which is a cause for concern. It is worth examining the factors that contribute to abnormally high SRB in more than one-third of the districts, especially now that birth rates are falling and access to ultrasound technology is expanding.

TABLE 1: Distribution of Districts by Regions According to the Level of Under-One Sex Ratio

\begin{tabular}{lcccc}
\hline Sex Ratio & Eastern Region & Middle Region & Western Region & Total \\
\hline$\leq 100$ & 0 & 7 & 5 & 12 \\
$101-105$ & 4 & 4 & 5 & 13 \\
$106-109$ & 1 & 6 & 8 & 15 \\
110 and above & 10 & 6 & 8 & 24 \\
\hline Number of districts & 15 & 23 & 26 & 64 \\
\hline
\end{tabular}

Source: MICS 2009 report.

\section{TRENDS IN OBSERVED AND DESIRED SRB ACROSS REGIONS}

Comparison of DSRB shows a large decrease (from 126 in 1993 to 111 in 2011) in the past two decades, suggestive of a shift from a culture of strong son preference. The strongest son preference was observed until 2000 as the DSRB was 121, followed by a steep decline in the next decade (Table 2). At the national level, a considerable decline in mean ideal family size from 4.5 to 2.2 took place in the past two decades (NIPORT et al. 2013). Increasingly growing preference for small family size has mainly contributed to such differences in the DSRB between surveys.

The desired sex ratio at birth varies by divisions/regions, with a divide between west and east/middle. Historically, the desired sex ratio has been lower in the western divisions, compared with the divisions in two other regions. High ratios (DSRB 109 or above) are found in five out of seven divisions (eastern: two, middle: two, western: one). All divisions have witnessed a decline in the DSRB. Despite a large reduction, higher DSRB prevails in the divisions of the eastern and middle regions than in the western divisions (Table 2).

${ }^{6}$ The Bangladesh Bureau of Statistics, in collaboration with UNICEF, has been conducting the Multiple Indicator Cluster Survey (MICS) since 1993 with the objective of generating information on the situation of children and women. In 2009, the latest MICS was conducted and a total of 333,201 women age $15-49$ were interviewed. 
TABLE 2: Regional Variations in Desired Sex Ratio at Birth in Bangladesh, 1993-2011

\begin{tabular}{llccc}
\hline Region & Division & 1993 & 2000 & 2011 \\
\hline \multirow{2}{*}{ Eastern } & Chittagong & 131 & 122 & 113 \\
& Sylhet* & N/A & 124 & 114 \\
\hline \multirow{2}{*}{ Middle } & Dhaka & 130 & 122 & 112 \\
& Barisal & 130 & 127 & 114 \\
\hline \multirow{2}{*}{ Western } & Khulna & 117 & 117 & 108 \\
& Rajshahi & 123 & 118 & 107 \\
& Rangpur** & $\mathrm{N} / \mathrm{A}$ & $\mathrm{N} / \mathrm{A}$ & 110 \\
\hline Total & & 126 & 121 & 111 \\
\hline
\end{tabular}

Source: DHS data.

* Sylhet was split off from Chittagong in 1998.

**Rangpur was split off from Rajshahi in 2010.

No change in the observed sex ratios over the past two decades (102 in 1993 and 103 in 2011) implies an absence of moral acceptance for sex selection. Yet, an unusual pattern is noticed in the changes of observed sex ratio across regions. Over the period, an increase in the sex ratio is observed in three divisions (Barisal, Dhaka, and Khulna) while the two other divisions (Chittagong and Rajshahi) have experienced a decrease. (Sylhet was included in the Chittagong division until 1998.) After the split-off from Chittagong division, Sylhet experienced a high increase in OSRB. Like the DSRB, changes in the OSRB among Bangladesh's divisions over time are nearly patterned by a divide between west and east/middle (Table 3).

TABLE 3: Regional Variations in Observed Sex Ratio at Birth in Bangladesh, 1993-2011

\begin{tabular}{llccc}
\hline Region & Division & 1993 & $\mathbf{2 0 0 0}$ & $\mathbf{2 0 1 1}$ \\
\hline \multirow{2}{*}{ Eastern } & Chittagong & 116 & 99 & 98 \\
& Sylhet* & N/A & 95 & 112 \\
\hline \multirow{2}{*}{ Middle } & Dhaka & 92 & 114 & 105 \\
& Barisal & 106 & 133 & 123 \\
\hline \multirow{2}{*}{ Western } & Khulna & 81 & 115 & 96 \\
& Rajshahi & 109 & 99 & 92 \\
& Rangpur** & N/A & N/A & 103 \\
\hline Total & & 102 & 107 & 103 \\
\hline
\end{tabular}

Source: DHS data.

* Sylhet was split off from Chittagong in 1998.

**Rangpur was split off from Rajshahi in 2010. 


\section{THE GAP BETWEEN STATED AND ACTUAL SRB}

Bongaarts (2013) found that the DSRB exceeds the OSRB by a wide margin in all countries examined. Using DHS data, the present study identified a similar pattern in terms of the gap between desired and actual sex ratios across divisions. In six out of seven divisions, the DSRB exceeds the OSRB. All three western regions (Khulna, Rajshahi, and Rangpur) had higher desired sex ratios than the observed. Surprisingly, the observed sex ratio is higher than the desired in one middle division (Barisal). It is possible that women may state a lower DSRB in response to the government campaign of a small-family norm. The difference between observed and desired ratios is smallest in Sylhet division and highest in Rajshahi and Chittagong divisions (Figure 4).

FIGURE 4: Differences between Desired and Observed Sex Ratios at Birth by Divisions in Bangladesh, 2011

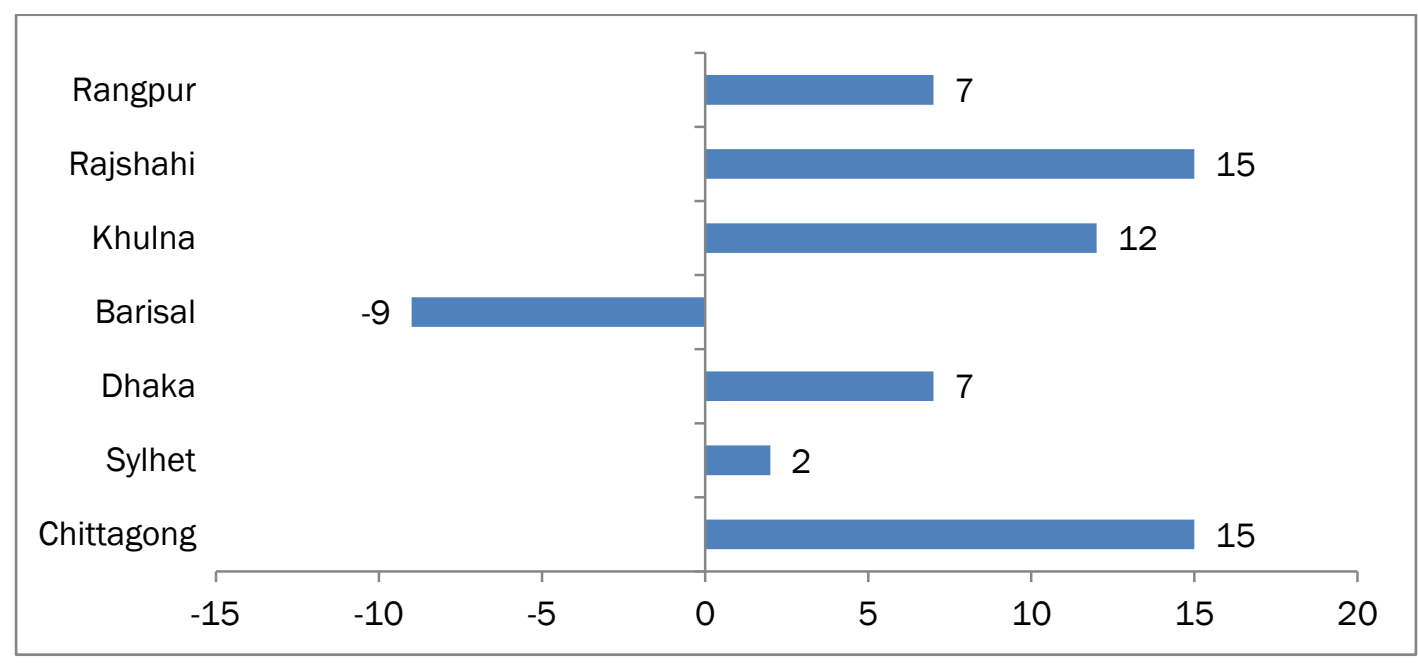

Source: DHS data.

\section{Socio-demographic differentials in sex ratio at birth}

Using DHS data this study has attempted to explore the relationship between socio-demographic variables and the SRB. The following discussions present differentials in the SRB by education, socio-economic status, and parity. Disaggregation of small samples (of the OSRB data) in estimating differentials may explain erratic or large fluctuations in the OSRB.

An inconsistent inverse relationship exists between the OSRB and women's level of education. The likelihood of having more sons than daughters is remarkably lower among women with higher-level education (i.e., above secondary level). Surprisingly, illiterate women had normal sex ratios at birth. DHS data shows a SRB of 114 among the women with primary-level education compared with 78 among those who had higher levels of education, indicating that women with higher-level education have less son preference. On the other hand, a consistent inverse relationship is found between the DSRB and the level of education. The rate of reduction in the DSRB is consistent with the increase in the level of education (Figure 5). 
FIGURE 5: Desired and Observed Sex Ratios at Birth by Education and Economic Status in Bangladesh, 2011

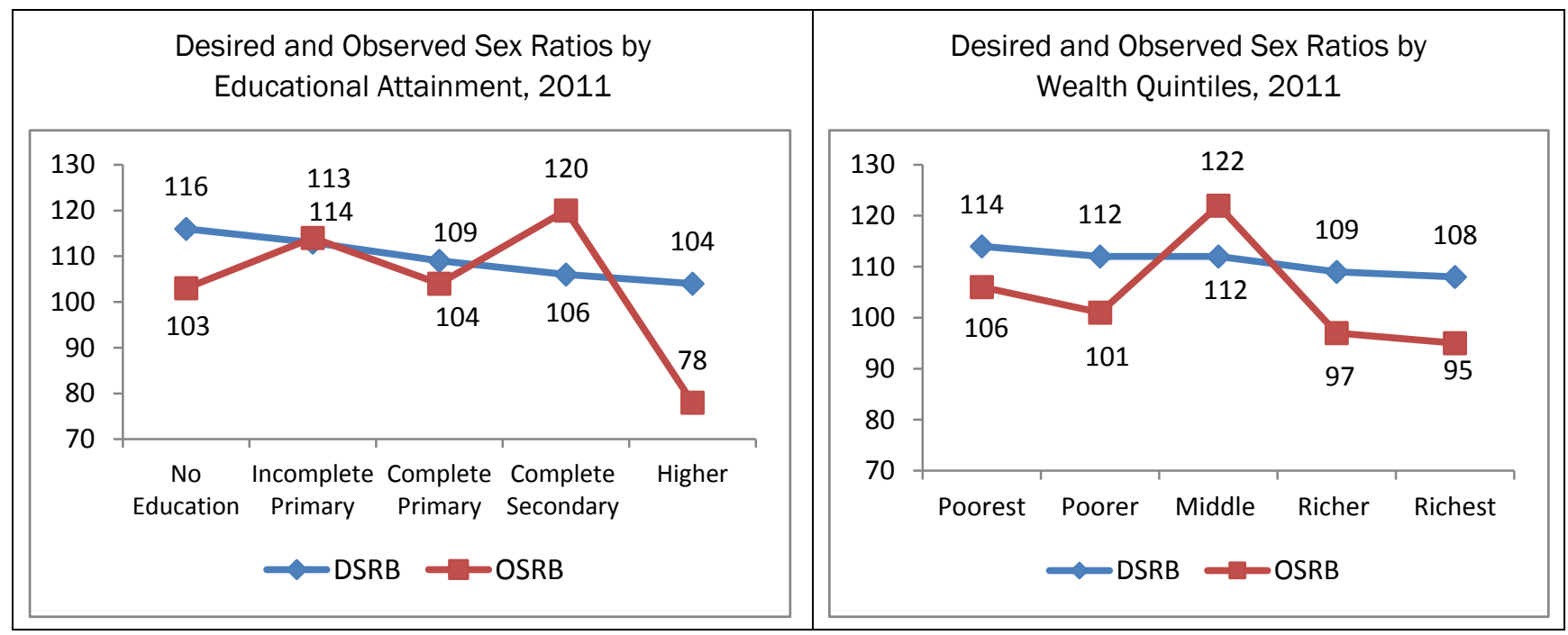

Source: DHS data.

Figure 5 reveals a linkage of OSRB with household wealth. Male-biased sex ratio increases from poorest to the middle wealth group and then it plummets among the wealthiest women. One possible explanation is that women in the poorest wealth group want to limit their family size without any gender preference due to economic hardship, but with improvement in economic status they can implement their choices. Women from the wealthiest households have fewer sons than daughters at birth. A more consistent inverse relationship exists between DSRB and socio-economic status. Stated preference for sons decreases with increasing household wealth status (Figure 5).

Analysis of DHS 2011 data reveals an inverse relationship between the sex ratio of all births (living children) and parity. As shown in Figure 6, a shift is noticed from a sex ratio of living children in favor of boys to a sex ratio of living children in favor of girls with the increase in parity, reflecting a malechild preference in the fertility outcomes among couples in Bangladesh. Among women with one child, the sex ratio is 110 , which means the majority of women have a male child. More sons than daughters are also observed for couples with two children. Women with five or six children have a sex ratio around 90, indicating a higher number of daughters than sons. Bongaarts (2013) similarly illustrated that in a population in which this particular childbearing pattern prevails, couples would have exactly one son (or, in rare cases, no sons) but can have any number of daughters. In case of strong son preference, women continue childbearing until a son is born and in the process a femalebiased sex ratio emerges among high-parity women. 
FIGURE 6: Desired Sex Ratio at Birth and Sex Ratio of All births by Parity in Bangladesh, 2011

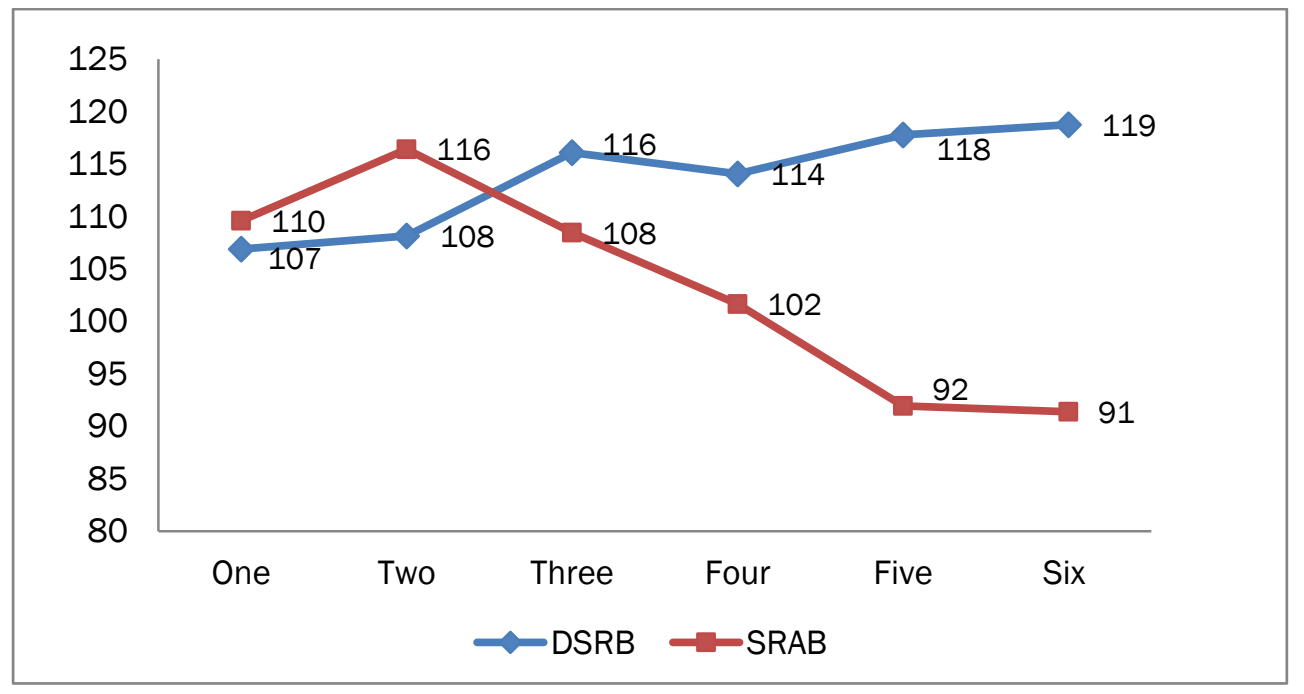

Source: DHS data. DSRB = Desired sex ratio at birth. SRAB = Sex ratio of all births (living children).

In contrast, the DSRB is positively associated with increasing parity (Figure 6). Couples with more children wanted more sons than daughters. Because couples with 1-2 children are likely to be younger than couples with a higher number of children, it can be inferred that the preference for more sons than daughters is stronger among older women than among women in younger age groups. These associations suggest a gradual weakening of the preference for male children in the course of time.

Comparison of DHS surveys from 1993 to 2011 reveals an increase in the proportion of women who prefer a two-child family with balanced sex (from 54 to 63 percent). A moderate preference for more sons than daughters exists where only 8 percent of the women expressed a preference for "two boys with one girl," which dropped from 21 percent in 1993-94. In contrast, a weak preference for daughters is observed, as only one percent of the women expressed a preference for "two girls with one boy." Preference for higher number daughters than sons remained the same over the past two decades, while preference for a higher number sons than daughters decreased markedly over the same period. The proportion of the women intending to have a four-child family with balanced sex (two boys and two girls) fell from 8 to 5 percent over the past two decades, indicating the reluctance of women to bear many children as their predecessors did. Currently, 19 percent of the women surveyed claimed to have no gender preference, which rose from 2 percent in 1993 (Figure 7). This growing indifference to the sex of the child is apparently attributable to social and economic development encouraged by the government, which has weakened the strength of son preference and promoted a small family norm. 
FIGURE 7: Trends in Gender Preferences at Birth among Women in Bangladesh, 1993-2011

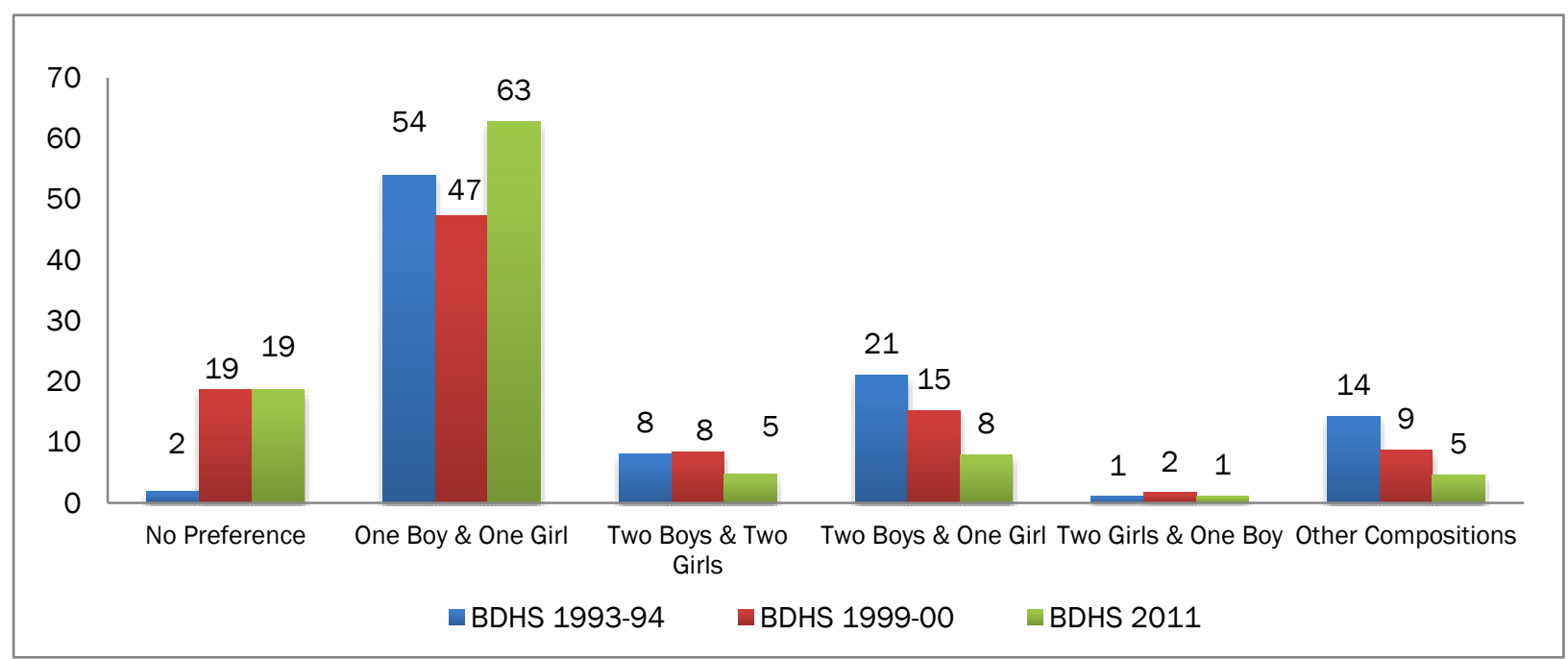

Source: DHS data. Other compositions include combinations of only boy(s) and girl(s) and any mixed composition having three or more sons and/or daughters and those refer God's will in determining child-gender.

Comparison of gender preferences across regions shows the dominance of a two-child family with one boy and one girl preference among women, with some variations. The proportion of women preferring such a balanced-sex two-child family is highest in the western region and lowest in the eastern region. While nine percent of women in the eastern region expressed a preference for a fourchild family with balanced gender, women are reluctant to bear many children in two other regions because only three percent expressed the same. The preference for sons is greater than that for daughters (10 percent vs. 2 percent). There is an east-west divide in son preference (12 percent vs. 8 percent), while no divide is observed for daughter preference ( 2 percent). Yet, one in five women has no preference for child gender, with small variations across regions (Table 4).

TABLE 4: Regional Variations in Gender Preference at Birth among Women in Bangladesh, 2011

\begin{tabular}{|c|c|c|c|c|c|c|c|}
\hline Region & $\begin{array}{r}\text { No } \\
\text { Preference }\end{array}$ & $\begin{array}{r}\text { Balance } \\
\text { Preference } \\
\text { (1 Boy \& } 1 \\
\text { girl) }\end{array}$ & $\begin{array}{r}\text { Balance } \\
\text { Preference } \\
\text { (2 Boys \& } 2 \\
\text { girls) }\end{array}$ & $\begin{array}{r}\text { Son } \\
\text { Preference* }\end{array}$ & $\begin{array}{l}\text { Daughter } \\
\text { Preference** }\end{array}$ & Others*** & $N$ \\
\hline Eastern & 19.3 & 53.8 & 8.8 & 11.8 & 1.9 & 4.4 & 4,959 \\
\hline Middle & 20.0 & 63.4 & 3.1 & 10.7 & 1.5 & 1.3 & 5,150 \\
\hline Western & 17.5 & 68.4 & 3.0 & 8.3 & 1.9 & 0.9 & 7,733 \\
\hline National & 18.7 & 62.8 & 4.7 & 10.0 & 1.8 & 2.0 & 17,842 \\
\hline
\end{tabular}

Source: DHS data.

*Son preference includes: Two boys, one boy, and two boys and one girl.

$* *$ Daughter preference includes: Two girls, one girl, and two girls and one boy.

$* * *$ Others include other combinations of sons and/or daughters and those refer God's will in determining child-gender. 
As the two-child family norm is being ingrained culturally among couples in Bangladesh, this study attempts to explore future fertility intention among couples having two children. Figure 8 shows a decrease in future fertility intention among couples with two children, which varies by the sex composition of existing children. The largest decrease is observed among women with "two boys" followed by women with "one boy and one girl," indicating the weakening of son preference over time. The popularity of the "one boy and one girl" composition is about to become universal, as only nine percent of the women with a balanced sex composition of children want an additional child in the future.

FIGURE 8: Future Fertility Intention among Women with Two Children in Bangladesh, 1993-2011

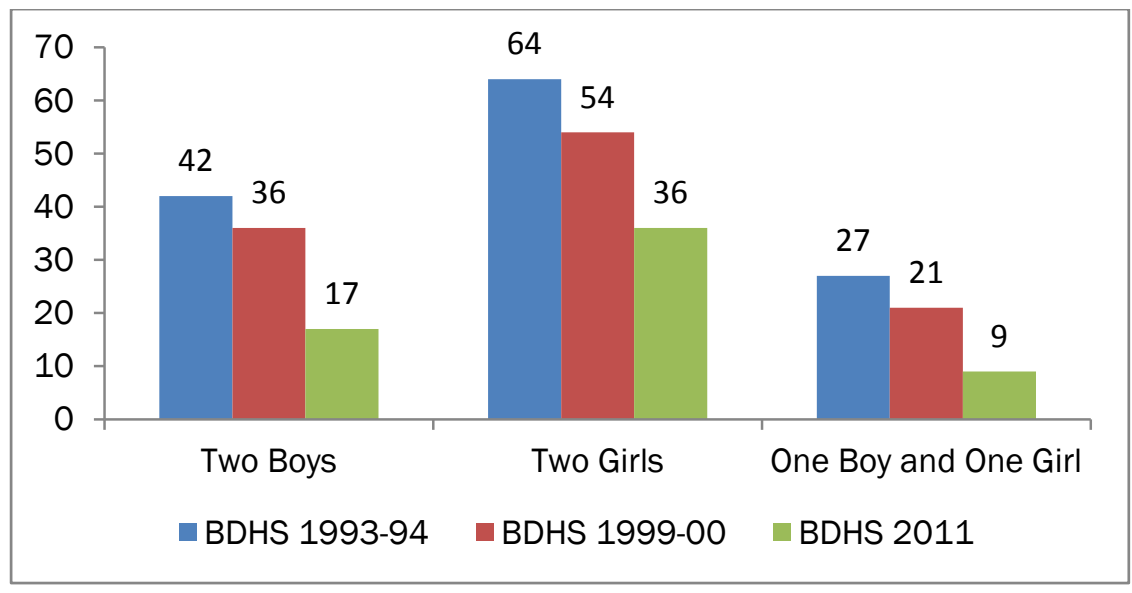

Source: DHS data.

Two decades earlier, 64 percent of the women who had two girls wanted an additional child, suggesting that they were not satisfied with the composition of their children; this sharply reduced to 36 percent over time (Figure 8). These improvements are encouraging, yet further reduction in the proportion of the women with two girls intending to have an additional child in the context of a societal norm of a two-child family will testify to the value of girls at both household and national levels.

\section{EAST-WEST DIVIDE IN FERTILITY, SEX RATIO AT BIRTH, AND SON PREFERENCE}

Historically, populations in the eastern region (Chittagong and Sylhet) are conservative and this region has higher fertility rates than the national average. Both desired and actual fertility is highest in the eastern region and lowest in the western region (Khulna, Rajshahi, and Rangpur) (NIPORT et al. 2013). The eastern region also has a relatively higher SRB, both desired and actual (see Figure 3 and Map 1), which indicates a clear preference for male children. Moreover, an east-west divide in terms of sex composition of children desired is also noted, as women in the eastern region have a relatively higher preference for male children than women in the western region (see Table 4).

BOX 1: East-West Divide in Fertility, Sex Ratio at Birth, and Son Preference

\begin{tabular}{|l|l|l|}
\hline Indicator & West & East \\
\hline Fertility & Low & High \\
\hline SRB & Low & High \\
\hline Son preference & Low & High \\
\hline
\end{tabular}




\section{Regional variations in menstrual regulation}

Figure 9 shows an interesting pattern in the rate of menstrual regulation (MR) across regions. The rate of MR performed per 1,000 women age 15-44 is lowest in the eastern region (Chittagong and Sylhet) and highest in the western region (Khulna, Rajshahi, and Rangpur). Generally, skewed SRB is related to a high rate of abortion and vice versa. The eastern region is a paradox where higher SRB coexists with the lowest level of MR. The lowest SRB exists in the western region and surprisingly the rate of MR is the highest in that region.

FIGURE 9: Regional Variations in the Rate of Menstrual Regulation per 1,000 Women Age 15-44

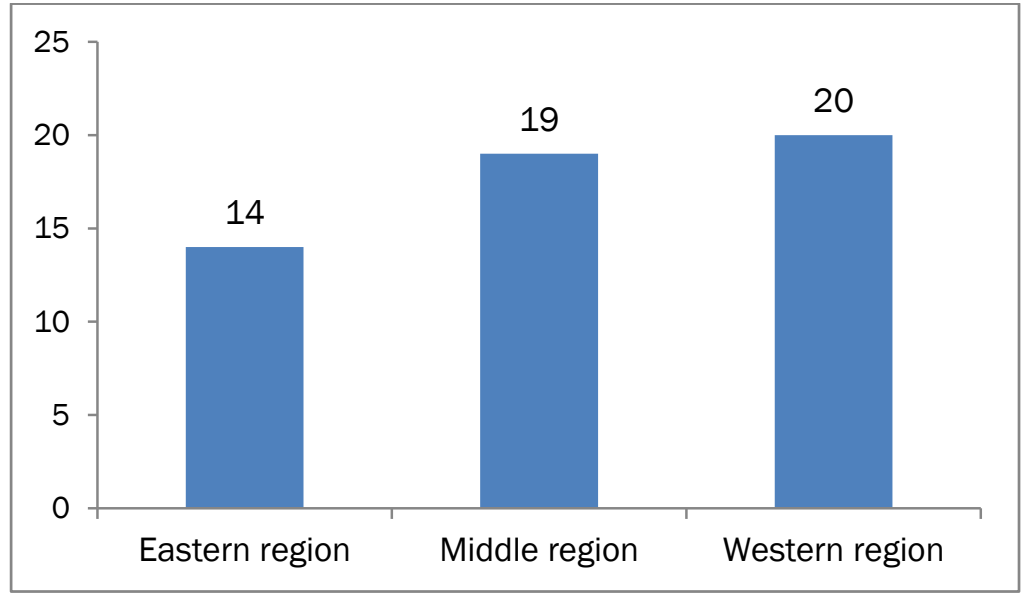

Source: Vlassoff et al. 2012.

Overall, the rate of abortion is high but it is not clear whether abortions are sex-selective or not. High SRB can be explained by the use of fertility-stopping strategies-either contraception or MR/abortion after a son is born to a woman. There are several studies that focus on the use of MR or abortion to achieve desired family size, and the purpose of abortion (limiting fertility) is found to be the same among women across regions. When women's contraceptive use fails to keep fertility within the desired level, women turn to MR or abortion.

Gipson and Hindin (2008), using longitudinal data from a surveillance area operated by the ICDDR,B in one district in western Bangladesh, found no evidence that the sex composition of surviving children affected the likelihood of abortion. Instead the most important influence on the likelihood of abortion was whether couples had expressed a desire for more children or not (Huq et al. 2012). Using the data from the Demographic Surveillance System of the ICDDR,B, Bairagi (2001) observed an absence of evidence of sex-selective abortion in Matlab, located in the eastern region of the country. The author concluded that induced abortion in Matlab is not related to the sex of the fetus. Both Bairagi (2001) and Gipson and Hindin (2008) observed that the abortion ratio increased with parity. Married women aged 35 years or older were more than four times as likely as married women younger than 25 years to terminate their pregnancy (Gipson and Hindin 2008). Bairagi (2001) estimated the abortion ratio within parities and found that it was generally lowest for women with no sons and was often highest for those with at least two sons and a daughter, suggestive of a stopping strategy. 


\section{E. Girl-child mortality}

According to economist Amartya Sen, gender inequality in many parts of the world takes the form of unusually high mortality rates among women at all ages. Female disadvantage in mortality of children reflects anti-female bias. This condition results in a skewed SRB and an even more skewed under-five sex ratio (UNICEF 2011). The following discussion highlights the situation of girl-child mortality in the country.

As shown in Table 5, Bangladesh has achieved notable progress in reducing girl-child mortality in the past two decades, as the rate of decline for female children has been greater than for male children. In the 1990s, male and female under-five mortality rates (U5MRs) were almost the same (149 and 150 per thousand live births respectively). In recent years, the U5 mortality rate has come down steeply to 57 per 1,000 live births for male children and even lower for female children (50 per 1,000 live births).

TABLE 5: Mortality between Male and Female Children in Bangladesh, 1993-2011

\begin{tabular}{lrrrrrrrr}
\hline & \multicolumn{3}{c}{ Male } & & \multicolumn{3}{c}{ Female } \\
\cline { 2 - 4 } \cline { 7 - 9 } Mortality Category & $1993-94$ & $\begin{array}{r}1999- \\
2000\end{array}$ & 2011 & & $1993-94$ & $1999-$ & 2011 \\
Neonatal mortality rate & 71 & 55 & 39 & & 56 & 46 & 26 \\
Infant mortality rate & 107 & 82 & 48 & & 93 & 77 & 37 \\
Under-five mortality rate & 149 & 108 & & 57 & & 150 & 118 & 50 \\
\hline
\end{tabular}

Sources: Mitra et al. 1994; NIPORT et al. 2001; NIPORT et al. 2013.

The gap in neonatal and infant mortality rates between males and females has been widened in favor of females, resulting in higher mortality among male children than female children. Male neonates have a mortality rate of 39 per 1,000 live births, compared with 26 for female counterparts. Less female infants die before their first birthday than male infants (infant mortality is 37 for female children and 48 for male children) (Table 5). These remarkable improvements in the mortality of girls over boys suggest a lessening of discrimination toward the girl-child.

The MICS 2009 report made an attempt to see the variance between male and female child mortality across regions. A comparison between male and female U5MRs at the regional level suggests a lower mortality among female children, compared with that of male children in all divisions. Four out of six divisions performed better than the norm of 20 percent variance between male and female mortality in favor of girls. ${ }^{7}$ Variance in mortality in favor of girls is below the norm (20 percent variance between males and females) in Dhaka and Sylhet. The highest female U5MR is observed in Sylhet, while it is lowest in Khulna, indicating a clear east-west divide in lowering female under-five deaths (Table 6).

7 The generally accepted differential between male and female mortality is a 20 percent variance between the two, in favor of girls (UNICEF 2011). 
TABLE 6: Regional Variations in Male and Female Under-Five Mortality Rates in Bangladesh, 2009

\begin{tabular}{llrrr}
\hline Region & Division & $\begin{array}{r}\text { Male } \\
\text { U5MR }\end{array}$ & $\begin{array}{r}\text { Female } \\
\text { U5MR }\end{array}$ & Female lower by \% \\
\hline \multirow{2}{*}{ Eastern } & Chittagong & 63 & 49 & $22 \%$ \\
& Sylhet & 81 & 66 & $19 \%$ \\
\hline \multirow{2}{*}{ Middle } & Barisal & 67 & 51 & $24 \%$ \\
& Dhaka & 74 & 60 & $19 \%$ \\
\hline \multirow{2}{*}{ Western } & Khulna & 68 & 45 & $34 \%$ \\
& Rajshahi & 75 & 57 & $24 \%$ \\
\hline
\end{tabular}

Source: MICS 2009 report.

Similarly, there has been a practice of equality in nutrition, as reflected in nearly equal reduction in underweight children for both males and females. The proportion of underweight female children has decreased from 58 percent in 1996-97 to 39 percent in 2011. In the case of male children, it has decreased from 55 percent to 35 percent (Mitra et al. 1997; NIPORT et al. 2013).

Female disadvantage in mortality has declined substantially since the 1990s. Significant improvement in the mortality and nutrition situation of girls indicates families' commitment to raise the value of girls within households. Improvements in the survival chances of girls relative to boys documented in Bangladesh's national statistics are consistent with, and may be driven by, the weakening of son preference (Kabeer et al. 2013). Government health care is available free of charge in rural areas so that parents are not deterred by financial constraints from seeking health care for their daughters. These are considered necessary conditions for establishing a genderbalanced society and imply an absence of postnatal sex selection. 


\section{INITIATIVES TO BUILD GENDER EQUALITY}

Relentless endeavor is underway by the government to adopt appropriate policies and strategies for the realization of women's empowerment. At the same time, a range of initiatives is ongoing to improve women's access to opportunities for education, employment, and other resources. This literature review focuses on the successes of selected gender-equality initiatives in the country, particularly continuing gender parity in school enrollment and increased female labor-force participation. The role of advocacy and community mobilization efforts to increase women's awareness of gender equality is also highlighted.

\section{A. Legal, social, and economic initiatives}

\section{LAWS, POLICIES, AND INSTITUTIONS PROMOTING GENDER EQUALITY}

Since its early days as an independent country, the government of Bangladesh has written policies and plans that are sensitive to the situation of women and their role in the society. Bangladesh's social and political institutions, such as courts, law and order, and civil society play a supportive role in protecting women's rights (Islam and Dogra 2011). Gender issues today are not merely special concerns but are considered crucial elements in the policies, plans, and strategies of the government.

- At the international level, Bangladesh is a signatory to the Convention on the Elimination of All Forms of Discrimination Against Women (CEDAW), to which it is committed to ensure the rights of women and eliminate gender inequality.

- The Bangladesh constitution upholds the principle of equality for men and women and prohibits discrimination against women. It grants equal rights to women and men in all spheres of public life and has been supplemented by a number of acts and ordinances to safeguard women's equal rights. It also provides reserved seats for women in the Parliament and promotes special representation for women in local government.

- Laws have been introduced to protect equality of rights and opportunities, such as the Dowry Prohibition Act of 1980, the Child Marriage Restraint Act (amended in 1984), and the Family Courts Ordinance of 1985. Through laws, provision has been made for punishment for actions and practices such as giving and taking dowry, abduction of women, dowry-related violence, and trafficking of girls and women. Child marriage (under the age of 18 for females) has been made a punishable offense.

- The Ministry of Women's and Children's Affairs was established in 1978 and is headed at the administrative level by a Secretary who reports directly to the Minister.

- In carrying forward CEDAW commitments, the government of Bangladesh formulated the National Policy for Advancement of Women in 1997 in the light of the constitution of Bangladesh, the CEDAW Convention, and the Beijing Platform for Action (BPFA). This policy includes commitments to eliminating discrimination against women and girls in all spheres and promoting women's equality in areas such as education and training, health and 
nutrition, housing and shelter, political empowerment and public administration, and the economy.

- A National Action Plan for women's advancement in implementing the policy as well as meeting commitments under the BPFA was approved in 1998, projecting the strategy of mainstreaming gender in all governmental policies by the sectoral ministries.

- Furthermore, the National Council for Women's Development headed by the prime minister has been working with a view to eliminating all forms of discrimination against women and integrating women into mainstream economic activities as well.

These policies, laws, and institutions provide part of the essential legal framework for protecting and promoting women's equal rights and are considered positive initiatives toward the improvement of the gender situation. It will take time to see the total impact of these initiatives at the national level.

\section{LAWS ON THE USE OF TECHNOLOGY FOR PRENATAL SEX SELECTION}

In Bangladesh, access to abortion services is legally restricted. Early abortion in the name of MR within ten weeks of gestation is permitted. The country is yet to introduce any technology for testing the DNA of fetuses for prenatal sex determination within the early gestational period. Ultrasound scanning is available for checking the health and position of the fetus. Existing abortion laws act as a deterrent to prenatal sex selection. Besides, widespread pregnancy termination (MR without detecting the sex of a fetus) within the early gestational period largely forestalls the need to use technology for sex selection. How effectively abortion law is implemented remains to be examined.

\section{Laws imposing restrictions on access to safe abortion service}

In Bangladesh, abortion is illegal, permitted only as a lifesaving means. The law (Penal Code Sections 312-316) permits abortion only for the good faith of saving the life of the woman (UN 2002). Legal abortions must be performed by a qualified physician in a hospital. Performing abortion also requires the approval of two physicians. Violation of abortion law is embodied with harsh punishments for both service providers and clients, with three to ten years' imprisonment or a fine or both penalties.

\section{Laws imposing time limits on access to safe abortion service}

Starting in the late 1970s, menstrual regulation, the regularizing of menstruation by terminating the fetus within six to ten weeks of a missed period, has been permitted under the law (Bhuiya et al. 2001; Islam and Chowdhury 2012). In 1979, the government circulated a memorandum that authorized "menstrual regulation" as a family planning method (Oliveras et al. 2007; Islam and Chowdhury 2012). MR legislation has brought flexibility to the access of safe abortion services and allowed the integration of MR services into the national family planning program.

Menstrual regulation is not regulated by the Penal Code because it is considered "an interim method for establishing nonpregnancy" (Piet-Pelon 1997; Islam and Chowdhury 2012). The procedure is not legally defined as abortion because it is performed up until the tenth week within a missed menstrual period, usually before the pregnancy is clinically confirmed. Menstrual regulation is legal if 
it is done within six to ten weeks of gestation, whereas after ten weeks it is considered an abortion and therefore illegal in Bangladesh. No approval is required in performing MR. Trained nurses and female paramedics are allowed to provide MR services if the length of gestation is no more than eight weeks, while physicians can do so through ten weeks of gestation.

Adoption of the MR policy in 1979 was a timely initiative of the government to address women's unmet need for regulating their fertility when the country was experiencing high fertility. The government does not feel that MR service conflicts with current abortion laws as it provides MR as a family planning method not as an abortifacient (Islam and Chowdhury 2012).

\section{Implementation of abortion/MR laws}

Implementation of MR legislation or abortion law is weak. Most pregnancy terminations occur after the legal boundary of MR (ten weeks of gestation) in Bangladesh (Islam and Chowdhury 2012), and none are officially recorded. The average time at which pregnancy terminations occur is 3.5 months of gestation (Islam and Chowdhury 2012). Because criminal law requires that pregnancy be established for the purpose of prosecuting the offense of abortion, the use of MR makes it virtually impossible for the prosecutor to obtain the required proof.

Encouragingly, a recent study reveals compliance of service providers with the legal limit of ten weeks of gestation for performing MR procedures. An estimated 26 percent of women seeking MR services were rejected and only 57 percent of facilities that would be expected to provide MR services actually did so (Singh et al. 2012). The most common reason was exceeding the official limit of weeks since the last menstrual period. Other reasons for which service providers did not provide MR services were either religious or cultural (Vlassoff et al. 2012).

\section{What's next?}

Several studies have indicated that a large number of pregnancy termination procedures in Bangladesh take place beyond ten weeks after a missed menstrual period. Skewed SRB is supposedly related to the higher incidence of MR/abortion, but it is not clear whether abortions are sex-selective or not. A study on the use of ultrasound by pregnant women and the extent to which women seek to know the sex of the fetus will provide useful information on the prevalence of sexselective abortion. It is of particular importance to know the provider perspective regarding the reasons for large numbers of pregnancy terminations and the use of ultrasound technology for sex selection. 


\section{GENDER EQUALITY IN EDUCATION}

Significant progress has been made in reducing the gender gap in school enrollment, primarily the result of effective public interventions in the education sector (Asadullah and Chaudhury 2006). Strategies to improve girls' educational participation have included two broad policy interventions: (1) social transfers and (2) educational investments on the supply side, such as building more schools, providing girl-friendly facilities, and recruiting more female teachers (Asadullah and Chaudhury 2006). Notably, the government introduced a financial incentive program to ensure gender equality in education, known as the Female Secondary-School Stipend Project (FSSP).

\section{Female Secondary-School Stipend Project}

To help reduce child marriage, the government of Bangladesh launched a nationwide conditional cash transfer (CCT) initiative in the education sector in 1994 to incentivize families to delay their daughters' marriages. The stipend program for girls in secondary school (grades 6-10) is implemented in all upazilas (subdistricts) of the country, with support from the World Bank, the Asian Development Bank, and the Norwegian Agency for Development Cooperation (Mahmud 2003). The objectives of this program are to: (1) increase school enrollment among secondary-school-aged girls; (2) improve the secondary schooling completion rate for girls; and (3) increase female age at marriage (Khandker et al. 2003). In addition, this stipend program is complemented by other components such as curriculum reforms and instructional materials development, teacher training, recruitment of female teachers, improvement of school infrastructure, awareness programs at the community level, and institutional capacity building (Khandker et al. 2003).

The program provides a stipend and tuition subsidy to each girl attending a secondary school in the rural areas who satisfies the following eligibility criteria: (1) attend 75 percent of school days; (2) attain a minimum level of measured academic proficiency ( 45 percent marks at the half yearly/annual examination); and (3) remain unmarried (Khandker et al. 2003). The total stipend amount is progressive across grades. The tuition part of the stipend is paid directly to the school and the CCT is directly deposited in two installments annually to the savings account of the student in a commercial bank (Asadullah and Chaudhury 2006).

\section{Achievements}

- Closing the gender gap. There has been a considerable rise in female enrollment at the secondary-school level, from one million in 1991 to more than six million in 2012 (World Bank 2012). Currently more than half of the total enrollment, approximately 53 percent of enrolled students, are female, largely due to the introduction of the FSSP that provides a cash incentive to households to cover a large portion of direct school expenses incurred by girls in grades six to ten (Khandker et al. 2003; Asadullah and Chaudhury 2006; KFW 2006; Islam and Dogra 2011). The stipend program is seen as one mechanism for improving gender equity and increasing girls' access to secondary education (Mahmud 2003). Mahmud (2003) observed that this stipend not only offered financial support but was also a symbol of encouragement and recognition of the right of girls to an education. 
- Expansion to higher secondary. The government has extended the stipend program to cover girls enrolled in higher secondary grades 11-12 (Mahmud 2003).

- Impact on community. The program appears to have created a positive attitude among community leaders and the general population toward girls' secondary education, which is indeed an achievement in a patriarchal society that values women's seclusion. It is noteworthy that the stipend program for secondary school girls was enthusiastically received in a patriarchal Muslim society such as Bangladesh without any resistance (Mahmud 2003).

\section{Challenges}

- Reversal of gender gap. Greater emphasis on girls' enrollment has resulted in an unintended outcome-what some analysts have termed the "reverse gender gap." A systematic educational gender imbalance in favor of girls is growing as a result of the sex-specific stipend program (Khandker et al. 2003). In this regard, the stipend program aided the process of closing the gender gap not solely by raising girls' enrollment but also by cutting back boys' participation in secondary school (Asadullah and Chaudhury 2006; Asadullah and Chaudhury 2009). Arends-Kuenning and Amin (2004), who examined the impact of the secondary-school female stipend scheme, conjectured that parents may have decided to send adolescent girls to school and adolescent boys to work in response to the incentive.

- Expenditure obligation. Supporting more than two million girls each year under this program has evolved into a major expenditure obligation for the government. The stipend budget alone accounts for more than 60 percent of the country's secondary-school development budget and 13 percent of the education-sector budget (Khandker et al. 2003).

\section{What's next?}

The conditional cash transfer program needs to be rigorously evaluated to assess its impact in delaying child marriage. Whether this stipend program for secondary-school girls increases the value of girls, reduces discrimination against girls, or changes parental attitudes on son preference is worth investigating.

\section{GENDER EQUALITY IN EMPLOYMENT}

Bangladesh has witnessed slow but steady progress in women's labor-force participation, from 4 percent recorded by the 1974 Bangladesh Census to 36 percent according to the 2010 Labor Force Survey (Kabeer et al. 2013). An increase in the percentage of the employed population has occurred, with a greater increase for women than men (Rahman 2012). Increasingly, women seek employment in diverse occupations. About 90 percent of the workers in the export garment industries in two megacities (Chittagong and Dhaka) are women, and about 90 percent of health and family planning workers in rural areas are women. In primary school, 60 percent of teachers are female. Now women are holding jobs in the police department, defense departments, universities, banks, health, private sectors, journalism, and in every governmental and nongovernmental organizations. At present about 16.2 million women are serving in various sectors of Bangladesh (BBS 2011), yet huge inequality exists in the employment sector of Bangladesh and female labor-force participation is onethird that of male participation (Khandaker 2013). 


\section{Programs/Initiatives}

Several factors have contributed to women's growing participation in income-earning activities. In rural areas the expansion of microcredit programs has been a major contributor to the transition to commercialization of women's work from subsistence economic activities and/or unpaid household work (Hossain and Tisdell 2005). In urban areas, the unprecedented growth of female labor-force participation can be attributed mainly to the massive expansion of export-oriented manufacturing industries, especially the labor-intensive readymade garment (RMG) industries (Hossain and Tisdell 2005). Apart from labor-intensive manufacturing, women are becoming competitive in the modern service sector (Islam and Dogra 2011).

- Microfinance and women's empowerment. Microfinance-providing self-employment and empowerment for millions of female entrepreneurs in Bangladesh-is an idea generated from the country that is becoming increasingly global (Islam and Dogra 2011). The microcredit program benefits poor women in more than one way: it enhances their security by giving them access to assets and rights, and it augments their self-respect and provides them with choices and independence (Kumar et al. 2013). Further, the World Bank (2007) has stated that microcredit programs have given women voice, solidarity, and the ability to access other services. The participation of women in microcredit programs has also increased their mobility (Kumar et al. 2013). Focusing on the impact of participation in microfinance by gender on household expenditure and assets in Bangladeshi villages, Pitt and Khandker (1998) found that female microcredit recipients (as opposed to male) are more successful in increasing women's nonland assets and children's education. The role of group lending and peer borrowers deters domestic violence and provides a way for women to save by keeping money away from their husbands (Islam and Dogra 2011).

- Rise of the apparel industry. Sectors such as manufacturing and the RMG industries have witnessed a considerable growth in female labor-force participation in Bangladesh. The rise of the apparel industry since the 1980s has provided women with opportunities to work outside the home for wages (Khosla 2009). The World Bank (2007) highlighted the willingness of rural households to send girls to work in cities and considered it remarkable geographic mobility for the rural female labor force. The industry, which is highly laborintensive, does not demand a highly educated labor force. This development perhaps separates Bangladesh from most South Asian economies which have been less successful in penetrating low-end manufacturing that could employ a large number of women who have a primary- or secondary-school education but minimal technical skills (Islam and Dogra 2011).

- Government service quota for women. Acknowledging the generally disadvantaged status of women in the country, a 10 percent quota for women (in addition to merit) has been effective in all government ministries, directorates, and autonomous bodies in Bangladesh since 1976 (KFW 2006). Other mandatory reservations for women in government services include: 15 percent quota in nongazetted posts in addition to merit and 60 percent of primary-school teacher posts. Quotas for women's recruitment and employment are strictly followed. At the individual ministry level, emphasis is placed on adhering to government quotas, giving women equal training opportunities, and creating a more female-supportive work environment. 


\section{Achievements}

- Greater employment opportunities for women. Women's participation in the labor force is higher than ever before in Bangladesh, and the rate of women's participation is considerably higher compared to most South Asian economies (Islam and Dogra 2011). While some of the rise in women's participation is poverty driven, the rise also reflects the expansion of economic opportunities from a number of different sources: government and NGO service provision; the growth of microfinance services targeted to women; and rapid expansion of female labor-intensive, export-oriented industries (World Bank 2007; Kabeer et al. 2013). While the labor-intensive apparel industry offers direct employment to 3 to 3.5 million people in cities, mainly women, microfinance offers easy access to credit for the poorest of the poor and helps create self-employment for about 20 million women, particularly from the countryside (Islam and Dogra 2011).

- Weakening of patriarchal culture. In the past, security was linked with dependence on men and hence sons were valued more than daughters (Ahmed and Bould 2004). However, with the advent of the readymade garment industry as well as other social changes in Bangladesh, female garment workers are now providing income support for their parents or widowed mothers. These functions could previously be fulfilled only by sons. This can change the expectation of the support that an adult daughter, married or unmarried, is capable of providing and may contribute to equalizing sons and daughters in the eyes of their parents (Ahmed and Bould 2004; Khosla 2009).

Women have capitalized on the advantages offered by employment in this industry and found creative ways to negotiate and manage the expectations of their families with their own desires for income and autonomy (Khosla 2009). A qualitative research study conducted by Ahmed and Bould (2004) echoed similar findings that employment creates a space in which these women can begin to make choices and decisions independent of the wishes of the men in their families. Similarly, Naved et al. (2001) found that garmentworkers seem to reveal more autonomy in the marriage process. Forty-four percent of workers who married after migration to cities for work have themselves selected their spouses, compared with only 14 percent who married before migration (Naved et al. 2001). Ahmed and Bould (2004) explored a crack in the traditional patriarchal family system, as men can no longer guarantee women and children lifetime support in the context of extreme poverty and landlessness. Rather, working female members of the family assist their husbands, brothers, and parents through wage employment (Ahmed and Bould 2004).

\section{What's next?}

Women's employment has provided some tangible benefits to the household's economic status and has helped to change social norms regarding female empowerment. However, evidence is missing concerning the program impact on couples' preferences for sons. Whether improved employment and economic opportunities for women have an impact on couples having a more balanced SRB is a matter for further research. 


\section{B. Advocacy and community mobilization}

Since the 1990s, efforts have been strengthened at the national and local levels to disseminate the benefits of girls' education (and encourage greater participation) and to raise awareness concerning gender equity and women's empowerment.

\section{GOVERNMENT INITIATIVE IN ADVOCACY}

In an effort to promote awareness about women's rights and gender equity and to discourage discriminatory behavior against women, the Bangladesh government-owned television channel broadcasts a daily 30-minute program that addresses education, health, and awareness-building issues. All of the programs on women's development follow the principles of CEDAW and the Convention on the Rights of Children. The government-owned radio broadcasts a daily 5 hours and 30 minutes program from its 12 centers and 6 units that focuses exclusively on women's advancement (GOB 2010). In addition to the existing government mass media functionaries, private FM radio and community radios disseminate information to the remote areas of the country. Community radios in particular are concentrating on children's and women's issues at the grassroots level (GOB 2010).

In compliance with the policies on "Corporate Social Responsibility," large commercial entities and financial institutions carry out a range of publicity efforts, both outreach and mass media, to raise awareness on gender issues and the rights of women in accessing social, legal, and economic opportunities.

\section{Achievements}

Mass media, particularly radio and television, exerts a great influence on people's awareness, attitudes, and behavior regarding reproductive health through different entertainment/educational programs. Changes in the demand for children are believed to be in part a result of the government's strong and relentless advocacy for a two-child family for more than three decades. The National Population Policy promotes a two-child family norm and emphasizes dissemination of the messagenot more than two children, but one is better. In assessing the impact of mass media exposure on fertility in Bangladesh, Khatun (2011) states that if a woman is exposed to media and family planning messages her fertility ideals decline by 11 percentage points. In another assessment relating to the effect of mass media on fertility in Bangladesh, Rabbi (2012) observed that advertisements, social dramas, documentaries, or movies (related to consequences of mass population) are very motivational in changing fertility behavior, because people are influenced by the culture portrayed in these media and get exposed to ideas about a smaller family norm. The broadcasting of family planning messages through the radio seems to be popular in Bangladesh. According to UNFPA (1990), the population programs on Bangladeshi radio are probably the best in all of South Asia and even the entire developing world. In addition, the government-owned television channel broadcasts a social drama, Meena, which appears to be a strong advocacy effort aimed at eliminating discrimination against daughters. 


\section{What's next?}

The role of the media in changing fertility levels is well recognized and documented. However, evidence is lacking on media initiatives that change the value of daughters or reduce son preference, because there are limited advocacy efforts intended to change discrimination against daughters or affect the sex composition of children.

\section{NGOS' ROLE IN COMMUNITY MOBILIZATION}

The role of NGOs in mobilizing women for a number of activities in Bangladesh is well known. In addition, NGOs seek to raise awareness about women's issues. NGOs are present in more than 70 percent of the villages in Bangladesh. NGO membership is strongly associated with various indicators of women's empowerment (Huq et al. 2012). During the last three decades, a dynamic and increasingly organized NGO movement has developed in Bangladesh and consequently a number of community-based organizations have emerged with a specific focus on gender equality (KFW 2006). A recent evaluation by the Netherlands government found that even among those NGOs that do not have a specific gender focus, most NGOs surveyed were contributing toward gender-equality objectives and between 50 and 100 percent of direct beneficiaries of evaluated NGO projects were women (Ministry of Foreign Affairs, Netherlands 2000).

The literature suggests that NGO interventions positively contribute to women's empowerment. Kabeer et al. (2013) stated that NGOs are not only important providers of social and financial services but they also act as important conduits for new norms and values at the grassroots level, particularly as a substantial percentage of them are funded by Western donors and subscribe to discourses of gender equality. NGOs may be facilitating changes in attitudes and practices within the wider society-including, of course, access to paid work and greater mobility in the public domain (Kabeer et al. 2013). The World Bank (2007) noted a shift toward women's empowerment brought about by NGOs. It illustrated that NGOs help change the traditional perception of women as dependents having little autonomy to one in which they can be perceived as key contributors to the household and can be active members of the community (World Bank 2007). Huq et al. (2012) hold a similar view that NGOs have played an important role in promoting women's economic activity in the villages of Bangladesh, helping to shift perceptions of women as liabilities to assets. Hossain and Tisdell (2005) reveal that NGO-financed development programs in rural Bangladesh significantly raised women's participation in household decision-making in addition to conferring on women a greater control over resources.

Encouragingly, there is evidence of increasing collaboration between NGOs and government. International NGOs have played an important role in strengthening and supporting national organizations and groups focusing on gender issues, particularly female empowerment in Bangladesh. Such organizations often provide an initial vehicle for highlighting sensitive social/cultural and gender issues that are more difficult for local NGOs to address (KFW 2006). 
TABLE 7: Key Programs and Interventions on Gender Equality in Bangladesh

\begin{tabular}{|c|c|c|c|c|}
\hline $\begin{array}{l}\text { Program/ } \\
\text { Intervention }\end{array}$ & Objectives & Activities & Effectiveness & Source \\
\hline $\begin{array}{l}\text { Female Secondary- } \\
\text { School Stipend } \\
\text { Program (FSSP) }\end{array}$ & $\begin{array}{l}\text { Incentivize } \\
\text { families to: } \\
\text { increase girls' } \\
\text { secondary- } \\
\text { school } \\
\text { enrollment and } \\
\text { completion; } \\
\text { delay their } \\
\text { daughter's } \\
\text { marriage }\end{array}$ & $\begin{array}{l}\text { - Stipends to girls in Classes } 6 \text { to } 10 \text { in all upazilas } \\
\text { - Eligibility criteria: rural; attends } 75 \% \text { of school days; } \\
\text { attains minimum academic proficiency (45\%); } \\
\text { remains unmarried } \\
\text { - Stipend covers full tuition and cash incentive } \\
\text { - Incentive amount increases with class } \\
\text { - Tuition paid directly to the school; stipend } \\
\text { deposited into girl's savings account } \\
\text { - Curriculum reform, instructional materials } \\
\text { development, other improvements in school quality }\end{array}$ & $\begin{array}{l}\text { - Not rigorously evaluated for its impact on delaying } \\
\text { marriage or changing parental preferences for girls vs. } \\
\text { boys }\end{array}$ & $\begin{array}{l}\text { Khandker et al. } \\
\text { 2003; Mahmud } \\
\text { 2003; Asadullah } \\
\text { and Chaudhury } \\
\text { 2006, } 2009\end{array}$ \\
\hline Microfinance & $\begin{array}{l}\text { To empower } \\
\text { women }\end{array}$ & - Microfinance opportunities for women & \multirow{3}{*}{$\begin{array}{l}\text { - Direct association between microfinance and women's } \\
\text { empowerment, e.g., female microcredit recipients more } \\
\text { successful in increasing women's nonland assets and } \\
\text { children's education than male recipients } \\
\text { - Group lending and peer borrowers deters domestic } \\
\text { violence and provides a way for women to save by keeping } \\
\text { money away from husbands } \\
\text { - Offers easy access to credit for the poorest of the poor } \\
\text { and helps create self-employment for about } 20 \text { million } \\
\text { women, particularly from the countryside } \\
\text { - Provides women wage-earning opportunity outside home } \\
\text { - Rural households send girls to work in cities-important } \\
\text { geographic mobility for the rural female labor force } \\
\text { - Employment in cities: } 3-3.5 \text { million people, mainly women } \\
\text { - Weakened the patriarchal structure } \\
\text { - Women's participation in the labor force is higher than ever } \\
\text { before and is higher than other South Asian economies }\end{array}$} & \multirow{3}{*}{$\begin{array}{l}\text { Pitt and Khandker } \\
\text { 1998; Naved et al. } \\
\text { 2001; Ahmed and } \\
\text { Bould 2004; } \\
\text { Hossain and Tisdell } \\
\text { 2005; KFW 2006; } \\
\text { World Bank 2007; } \\
\text { Khosla 2009; } \\
\text { Islam and Dogra } \\
\text { 2011; Kabeer et al. } \\
2013\end{array}$} \\
\hline $\begin{array}{l}\text { Rise of apparel } \\
\text { industry }\end{array}$ & $\begin{array}{l}\text { To enhance } \\
\text { women's } \\
\text { employment }\end{array}$ & $\begin{array}{l}\text { - The industry employs more than three million } \\
\text { people and women constitute the largest part of } \\
\text { the workforce. The industry, which is highly labor- } \\
\text { intensive, does not demand a highly educated } \\
\text { labor force. }\end{array}$ & & \\
\hline $\begin{array}{l}\text { Government service } \\
\text { quota for women }\end{array}$ & $\begin{array}{l}\text { To enhance } \\
\text { women's } \\
\text { employment }\end{array}$ & $\begin{array}{l}\text { - } 10 \% \text { quota for women (in addition to merit) in all } \\
\text { government ministries, directorates, and } \\
\text { autonomous bodies; } 15 \% \text { quota in nongazetted } \\
\text { posts in addition to merit, and } 60 \% \text { of primary- } \\
\text { school teacher posts }\end{array}$ & & \\
\hline $\begin{array}{l}\text { Government-owned } \\
\text { television channel } \\
\text { and radio; FM and } \\
\text { community radio }\end{array}$ & $\begin{array}{l}\text { Women's } \\
\text { empowerment }\end{array}$ & $\begin{array}{l}\text { - 30-minute daily television programs } \\
\text { - 51/2-hour radio broadcasts for women } \\
\text { - Social drama, Meena, intended to change } \\
\text { discrimination against daughters } \\
\end{array}$ & \multirow[t]{2}{*}{ Edutainment programs effective } & \multirow[t]{2}{*}{ GOB 2010} \\
\hline $\begin{array}{l}\text { Corporate Social } \\
\text { Responsibility efforts } \\
\text { by large commercial } \\
\text { entities }\end{array}$ & $\begin{array}{l}\text { Raise gender } \\
\text { issues }\end{array}$ & - Outreach and mass-media efforts & & \\
\hline $\begin{array}{l}\text { National Population } \\
\text { Program }\end{array}$ & $\begin{array}{l}\text { Promotion of } \\
\text { two-child norm }\end{array}$ & $\begin{array}{l}\text { - Dissemination of message "Not more than two } \\
\text { children; one is better" }\end{array}$ & $\begin{array}{l}\text { Fertility desires of women exposed to media messages fell } \\
\text { by } 11 \%\end{array}$ & $\begin{array}{l}\text { Khatun 2011; } \\
\text { Rabbi } 2012\end{array}$ \\
\hline NGO engagement & $\begin{array}{l}\text { Women's } \\
\text { empowerment }\end{array}$ & - Development programs in rural areas & NGO-supported programs improved women's agency & $\begin{array}{l}\text { Hossain and Tisdell } \\
\text { 2005; KFW 2006; } \\
\text { World Bank 2007; } \\
\text { Huq et al. 2012; } \\
\text { Kabeer et al. 2013 }\end{array}$ \\
\hline
\end{tabular}




\section{THE WAY FORWARD}

In Bangladesh, sex ratio at birth (SRB) has remained almost the same at 103 male per 100 female newborns in the past two decades, but with wide regional variations. Regional variations in SRB are characterized by an east-west divide. Women in the eastern region have more sons than daughters at birth, in stark contrast with women in the western region who have fewer sons than daughters at birth. Moreover, women in the eastern region have relatively higher preference for male children than women in the western region. Variations in SRB at the district level pose even greater concern. Future studies need to investigate the context for high sex ratios that prevail in the eastern region and in some districts.

Elevation in SRB is caused by three factors as identified by Guilmoto (2009): access to sex-selection technology; preference for sons; and low fertility. Bangladesh is a low-fertility country (total fertility rate stands at 2.3) where there is a potential risk for an elevation in SRB with the presence of two other preconditions: sex-selection technology and son preference.

Access to sex-selection technology partially exists in the country. Ultrasound is the only available technology for sex detection in Bangladesh. Use of ultrasound technology for sex selection is not common in Bangladesh even in the absence of policies/laws on the use of prenatal diagnostic techniques for sex selection. Many women undergo ultrasound scanning, largely to check the health and position of the fetus. Moreover, ultrasound scanning tends to be done too late in the pregnancy to allow legal abortion. The country is yet to introduce any technology for testing the DNA of the fetus for prenatal sex determination within the early gestational period.

The rate of pregnancy terminations (both MR and induced abortion) in the country is high but it is not clear whether abortions are sex-selective or not. Generally, skewed SRB is related to the high rate of abortion. Paradoxically, in the eastern region of Bangladesh, higher SRB coexists with the lowest level of MR. Overall, Bangladesh is yet to be threatened by high SRB and therefore no prohibition exists on sex-selective abortion as is the case for several developing countries in Asia, including China and India.

Unlike two high-SRB countries in Asia (China and India), Bangladesh is characterized by a nearabsence of sex-selective abortion. So far, Bangladesh has experienced a higher incidence of pregnancy termination for fertility control instead of sex selection, which can be explained by its large volume of legal pregnancy terminations within 10 weeks of gestation (without knowing the fetal sex) under the MR policy and the unavailability of DNA testing for sex detection within the early gestational period. The purpose of pregnancy terminations (i.e., limiting fertility) is found to be the same among women in eastern and western regions.

Generally, a strong preference for sons leads couples to discriminate between the sexes in different ways. In many societies that have a high SRB, son preference is manifested at three stages in the couple's fertility behavior: before conception, during pregnancy (prenatal), and during early childhood (postnatal). 
Son preference and family-building strategies are widely practiced before conception in Bangladesh. Sex composition of the child/children already born influences the couple's decision to use contraceptive methods or to have an additional child. The sex ratio of last birth bears witness to this phenomenon. Bongaarts (2013) states that high sex ratio of last birth (SRLB) is a highly sensitive indicator of sex-selective stopping behavior. Bangladesh has witnessed an ascent in the SRLB (from 117 in 1993 to 125 in 2011), despite a sharp decline in the desired sex ratio at birth (DSRB) (from 126 in 1993 to 111 in 2011). The rise in the SRLB in the country is consistent with the linkage of the reproductive outcomes for couples who want exactly one son and stop childbearing after a son is born. DHS data also reveal that women who have five or six children have an SRB of around 90, indicating a higher number of daughters than sons. These high parity women also expressed stronger son preference than young women. A similar context was illustrated by Bongaarts (2013) that in a population in which this particular childbearing pattern prevails, couples would have exactly one son (or, in rare cases, no sons) but can have any number of daughters.

Prenatal preference for sons is not widely observed in Bangladesh. There is an absence of evidence that son preference is practiced prenatally through sex determination and sex-selective abortion. Sex-selective abortion is religiously and culturally unacceptable and uncommon in Bangladesh. A strong small-family norm coexists with a prohibitive social culture of sex-selective abortion, yet this does not cause abnormally high imbalances in SRB. Postnatally, no strong evidence on ensuring son preference through neglect and abandonment of female children exists. Lower mortality among girls than boys during infancy and early childhood suggests a low discrimination against female children. Improvements in the survival chances of girls relative to boys may be driven by the weakening of son preference.

DHS data reveals a moderate presence of son preference among couples as a greater future fertility intention was evident among couples with two girls than among couples having two boys (36 percent vs. 17 percent). Although the preference for sons is present, couples also want a daughter. Evidence suggests that those who had at least one son and a daughter had the lowest fertility.

Recent changes in gender preference among couples are encouraging. A strong preference for the balanced sex composition of children is becoming common across the country. The popularity of "one boy and one girl" composition is about to become universal, as only nine percent of the women with such a balanced sex composition of children want an additional child in the future. Moreover, the preference for a greater number of sons than daughters has decreased markedly over the past two decades. It is also encouraging to note the drastic reduction in the proportion of women with two girls intending to have an additional child. Two decades earlier, 64 percent of women with two girls wanted an additional child, suggesting that they were not happy with their composition of children. This sharply reduced to 36 percent over time. All these improvements are encouraging, and thus a culture of son preference appears to be giving way to a growing indifference to the sex of a child. It is worth investigating how couples achieve balanced sex composition of children with a small number of children. Whether efforts to encourage gender equality or the strong family-planning program has contributed to progression toward the norm of a balance-gendered small family among couples is yet to be explored. 
A weakening of the preference for male children is evident from fertility ideals among young women. The desired SRB is positively associated with increasing parity. The preference for more sons than daughters is stronger among older women than women in the younger age groups. Largely, a woman's desire for a male child is likely to be affected by her level of education and wealth status. The preference for more sons than daughters is markedly lower among women with a higher level of education (i.e., above secondary level). Likewise, the preference for sons decreases with increasing household wealth status. The rural setting exhibits a preference for the male child. Women living in rural areas have a stronger desire to have more sons than daughters, compared with their urban counterparts.

Traditionally, the country is characterized by an absence of moral acceptance of sex selection, as DHS data reveal no change in the observed sex ratios over the past two decades (102 in 1993 and 103 in 2011). Son preference is not strongly linked to religion in Bangladesh, which is a moderate Muslim country where more than 90 percent of the population practices Islam as a religion. Son preference is not an Islamic practice as this religion does not promote strong son preference for religious ceremonies and family inheritance. Evidence suggests a stronger son preference among Hindu women than among Muslim women in Bangladesh.

There has been a reduction in the preferential treatment of males over females, which is represented by the improvements in women's social and economic position over the past 20 years in Bangladesh. The country has started to experience societal change in which daughters and sons can be perceived as equally valuable. These changes include greater acceptance of girl's education and women's employment, increased participation of women in decisions around childbearing, and a reduction in fertility. With the increased opportunities for education, paid employment, and microcredit, women now have a greater ability to function independently and provide income support to parents, which could previously only be fulfilled by sons. To what extent this change has penetrated into the societal norm is worth investigating.

Until now, growing preference for a small family with balanced sex composition of children, low female-child mortality rates, and a near-absence of sex-selective abortion in an environment of moderate Islamic culture have prevented SRB from going beyond the normal level in Bangladesh. Yet regional variation in the SRB remains a cause for concern. Further, Bangladesh may be threatened by high SRB if son preference prevails and if medical technology that enables detection of the sex of a fetus within the early gestational period is made available.

Opportunities exist for Bangladesh to adopt measures to prevent the elevation in SRB. The country needs to formulate policies/laws forbidding sex-selection technology and ensure their strict enforcement. Policies and strategies are in place to ensure equal opportunities for men and women. Yet expansion of social and economic opportunities for girls and women will hasten the process of reducing the preferential treatment of males over females as an indirect route to reducing son preference. Media mobilization has helped produce a decline in fertility in the country and hence may be a powerful tool for changing attitudes so that daughters are valued and awareness is raised about the dangers of gender imbalance. However, reducing son preference remains a big challenge for the policymakers of Bangladesh, because the country is still heavily rural and agrarian where poverty is widespread. 


\section{What's next?}

This literature review study has initiated a journey toward understanding the dynamics of the sex ratio at birth in Bangladesh. Absence of intensive studies and inadequacy of data have prevented us from delving into the issue further to unearth the mysteries behind SRB. We suggest several areas for future primary research that can generate evidence to fill gaps found in this study:

- The truth behind the east-west divide in the SRB in the country: what factors affected the unbalanced SRB?

- Women's awareness and views on ultrasound and abortion and their use for sex selection. How couples achieve a small family with balanced sex composition of children.

- Provider views on laws and use of ultrasound, particularly for sex selection. Provider experiences regarding sex-selective abortion. 


\section{REFERENCES}

Ahmed, S.S., S. Bould. 2004. "One able daughter is worth 10 illiterate sons": Reframing the patriarchal family," Journal of Marriage and Family 66(5): 1332-1341.

Arends-Keunning, M., S. Amin. 2004. "School incentive programs and children's activities: The case of Bangladesh," Comparative Education Review 48(3).

Asadullah, M.N., N. Chaudhury. 2006. "Conditional cash transfer and educational gender gaps: Insights from Bangladeshi households." Available at: http://paa2007.princeton.edu/papers/70330.

_. 2009. "Reverse gender gap in schooling in Bangladesh: Insights from urban and rural households,"Journal of Development Studies 45(8): 1360-1380.

Bairagi, R. 2001. "Effect of sex preference on contraceptive use, abortion and fertility in Matlab, Bangladesh," International Family Planning Perspectives 27(3): 137-143.

Bangladesh Bureau of Statistics (BBS). 2011. Report on Labor Force Survey 2010. Dhaka: BBS, Ministry of Planning, Government of Bangladesh.

Bhuiya, A., A. Aziz, M. Chowdhury. 2001. "Ordeal of women for induced abortion in a rural area of Bangladesh," Journal of Health Population and Nutrition 19(4): 281-290.

Bongaarts, J. 2013. "The implementation of preferences for male offspring," Population and Development Review 39(2): 185-208.

Chang, M. 1994. "Sex preference and sex ratio at birth: The case of Taiwan." Presented at the symposium on "Issues Related to Sex Preference for Children in the Rapidly Changing Demographic Dynamics in Asia." Seoul: UNFPA and Korean Institute of Health and Social Affairs.

Das Gupta, M., P.N.M. Bhat. 1997. "Fertility decline and increased manifestation of sex bias in India," Population Studies 51(3): 307-315.

Das Gupta, M., J. Zhenghua, L. Bohua, X. Zhenming, W. Chung, B. Hwa-OK. 2003. "Why is son preference so persistent in East and South Asia? A cross-country study of China, India and the Republic of Korea." Washington, DC: Development Research Group, World Bank.

Gipson, J.D., M.J. Hindin. 2008. "Having another child would be a life or death situation for her: Understanding pregnancy termination among couples in rural Bangladesh," American Journal of Public Health 98(10): 1821832. doi:10.2105/AJPH.2007.129262.

- 2009. "The effect of husbands' and wives' fertility preferences on the likelihood of a subsequent pregnancy, Bangladesh 1998-2003," Population Studies 63(2): 135-146.

Government of Bangladesh (GOB). 2010. Sixth Five Year Plan 2011- 2015: Accelerating Growth and Reducing Poverty. Dhaka: Planning Commission, Ministry of Planning, Government of Bangladesh.

Guilmoto, C.Z. 2009. “The sex ratio transition in Asia," Population and Development Review 35(3): 519549.

Hesketh, T., Z.W. Xing. 2006. "Abnormal sex ratios in human populations: Causes and consequences." Proceedings of National Academy Science 103(36): 13271-13275.

Hossain, M.A., C.A. Tisdell. 2005. “Closing the gender gap in Bangladesh: Inequality in education, employment and earnings," International Journal of Social Economics 32(5): 439-453.

Huq, L., N. Kabeer, S. Mahmud. 2012. "Diverging stories of son preference in South Asia: A comparison of India and Bangladesh." Working Paper No. 07. Dhaka, Bangladesh: BRAC Development Institute, BRAC University, Bangladesh.

Islam, N., S.A. Chowdhury. 2012. "The impact of imposing time limits on access to safe abortion care in Bangladesh.” Washington, DC: Center for Women Policy Studies. 
Islam, M.S., S. Dogra. 2011. "Women empowerment in Bangladesh: The rise of the other half." ISAS Working Paper No. 119. Singapore: Institute of South Asian Studies, National University of Singapore. Available at: http://www.isas.nus.edu.sg/PublicationByCategory.aspx.

Kabeer, N., L. Huq, S. Mahmud. 2013. "Diverging stories of "Missing Women” in South Asia: Is son preference weakening in Bangladesh?" Feminist Economics, doi: 10.1080/13545701.2013.857423.

KFW. 2006. Bangladesh Gender Profile. Discussion Paper 42. Available at: https://www.kfw-entwicklungsbank.de/migration/Entwicklungsbank-Startseite/ Entwicklungsfinanzierung/Themen/Gender/L\%C3\%A4nderprofil-Bangladesch.pdf.

Khandaker, M.M.R. 2013. "Gender discrimination in healthcare spending in the household and women's access to resources: Perspective of Bangladesh." Graduate research paper, University of Tokyo. Available at: http://www.pp.u-tokyo.ac.jp/courses/2013/documents/5140143_5a.pdf.

Khandker, S.R., M.M. Pitt, N. Fuwa. 2003. "Subsidy to promote girls' secondary education: The Female Stipend Program in Bangladesh." Available at: http://www.h.chiba-u.jp/mkt/revised\%20 fssap\%20paper9b.pdf.

Khatun, M.T. 2011. "Desired and actual fertility in Bangladesh: The role of mass media and social interactions." Graduate research paper. Hague, Netherlands: International Institute of Social Studies.

Khosla, N. 2009. "The ready-made garments industry in Bangladesh: A means to reducing gender based social exclusion of women?" Journal of International Women's Studies 11(1): 289-303.

Kim, D. 1997. "The pattern of changing trends and the regional differences in the sex ratio at birth: Evidence from Korea and Jilin province, China," Korea Journal of Population and Development 26(1): 19-42.

Kumar, D., A. Hossain, M.C. Gope. 2013. "Role of micro credit program in empowering rural women in Bangladesh: A study on Grameen Bank Bangladesh Limited," Asian Business Review 3(4): 114-120.

Mahmud, S. 2003. "Female secondary school stipend program in Bangladesh: A critical assessment." Dhaka, Bangladesh: Bangladesh Institute of Development Studies. Available at: http://portal.unesco.org/education.

Ministry of Foreign Affairs, Netherlands. 2000. "Evaluation of Netherlands-funded NGOs in Bangladesh." Policy and Operations Evaluation Department, Ministry of Foreign Affairs, Netherlands.

Mitra, S.N., M.N. Ali, S. Islam, A.R. Cross, T. Saha. 1994. Bangladesh Demographic and Health Survey, 1993-1994. Dhaka, Bangladesh and Calverton, Maryland: NIPORT, Mitra and Associates, and Macro International.

Mitra, S.N., A. Al-Sabir, A.R. Cross, K. Jamil. 1997. Bangladesh Demographic and Health Survey 19961997. Dhaka, Bangladesh and Calverton, Maryland: NIPORT, Mitra Associates, and Macro International.

National Institute of Population Research and Training (NIPORT), Mitra and Associates, ICF International. 2013. Bangladesh Demographic and Health Survey 2011. Dhaka, Bangladesh and Calverton, Maryland: NIPORT, Mitra and Associates, and ICF International.

National Institute of Population Research and Training (NIPORT), Mitra and Associates, ORC Macro. 2001. Bangladesh Demographic and Health Survey 1999-2000. Dhaka, Bangladesh and Calverton, Maryland: NIPORT, Mitra and Associates, and ORC Macro.

Naved, R.T., M. Newby, S. Amin. 2001. "The effects of migration and work on marriage of female garment workers in Bangladesh," International Journal of Population Geography 7(2): 91-104.

Oliveras, E., H. Johnston, L. Nahar, M.E. Chowdhury, A.A. Sabir, M.S. Islam. 2007. "Situation analysis of unsafe abortion and menstrual regulation in Bangladesh.” Dhaka: ICDDR,B. 
Piet-Pelon, N. 1997. "Menstrual regulation impact on reproductive health in Bangladesh: A literature review." Dhaka: Population Council.

Pitt, M., S.R. Khandker. 1998. "The impact of group-based credit programs on poor households in Bangladesh: Does the gender of participants matter?" Journal of Political Economy 106(5).

Rabbi, A.M.F. 2012. "Mass media exposure and its impact on fertility: Current scenario of Bangladesh," Journal of Scientific Research 4(2): 383-395.

Rahman, K.M.M. 2012. “Gender inequality in Bangladesh.” Policy Brief. Dhaka: Unnayan Onneshan.

Rahman, M., J. DaVanzo, A. Razzaque. 2001. “Do better family planning services reduce abortion in Bangladesh?” The Lancet 358: 1051-1056.

Razzaque, A., K. Ahmed, N. Alam, J.V. Ginneken. 2002. "Fertility intention and subsequent abortion in Matlab, Bangladesh," Journal of Health Population and Nutrition 20(4): 317-325.

Saha, U.R., R.Bairagi. 2007. "Inconsistencies in the relationship between contraceptive use and fertility in Bangladesh," International Family Planning Perspectives 33(1): 31-37.

Singh, S., A. Hossain, I. Maddow-Zimet, H.U. Bhuiyan, M. Vlassoff, R. Hussain. 2012. "The incidence of menstrual regulation procedures and abortion in Bangladesh," International Perspectives on Sexual and Reproductive Health 38(3): 122-132.

Streatfield, P.K. 2001. "Role of abortion in fertility control," Journal of Health Population Nutrition 19(4): 265-267.

UNFPA. 1990. Bangladesh, Report of Second Mission on Needs Assessment for Population Assistance. Report No. 80. New York: UNFPA.

UNICEF. 2011. "A perspective on gender equality in Bangladesh: From young girl to adolescent: What is lost in transition?" Dhaka: UNICEF Bangladesh. Available at: http://www.unicef.org/bangladesh/Gender_paper_Final_2011.pdf.

United Nations (UN). 2002. Abortion Policies: A Global Review. New York: United Nations. Available at: http://www.un.org.au/esa/population/publications/abortion/index.html.

_ 2013. World Population Prospects: The 2012 Revision. New York: Population Division, United Nations. Available at: http://esa.un.org/unpd/wpp/index.htm.

Vlassoff, M., A. Hossain, I. Maddow-Zimet, S. Singh, H.U. Bhuiyan. 2012. "Menstrual regulation and postabortion care in Bangladesh: Factors associated with access to and quality of services." New York: Guttmacher Institute. Available at: http://www.guttmacher.org/pubs/Bangladesh-MR.pdf.

World Bank. 2007. Whispers to Voices: Gender and Social Transformation in Bangladesh. Washington, DC: World Bank.

—. 2012. "Gender Statistics Highlights from 2012 World Development Report." World Data Bank, a compilation of databases by the World Bank. 


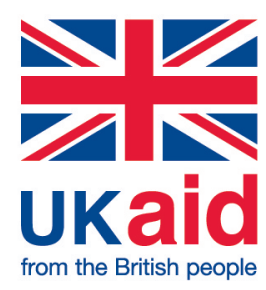

\section{POPULATION COUNCIL}

Ideas. Evidence. Impact. 